\title{
Secondary Education in India
}

November, 2003

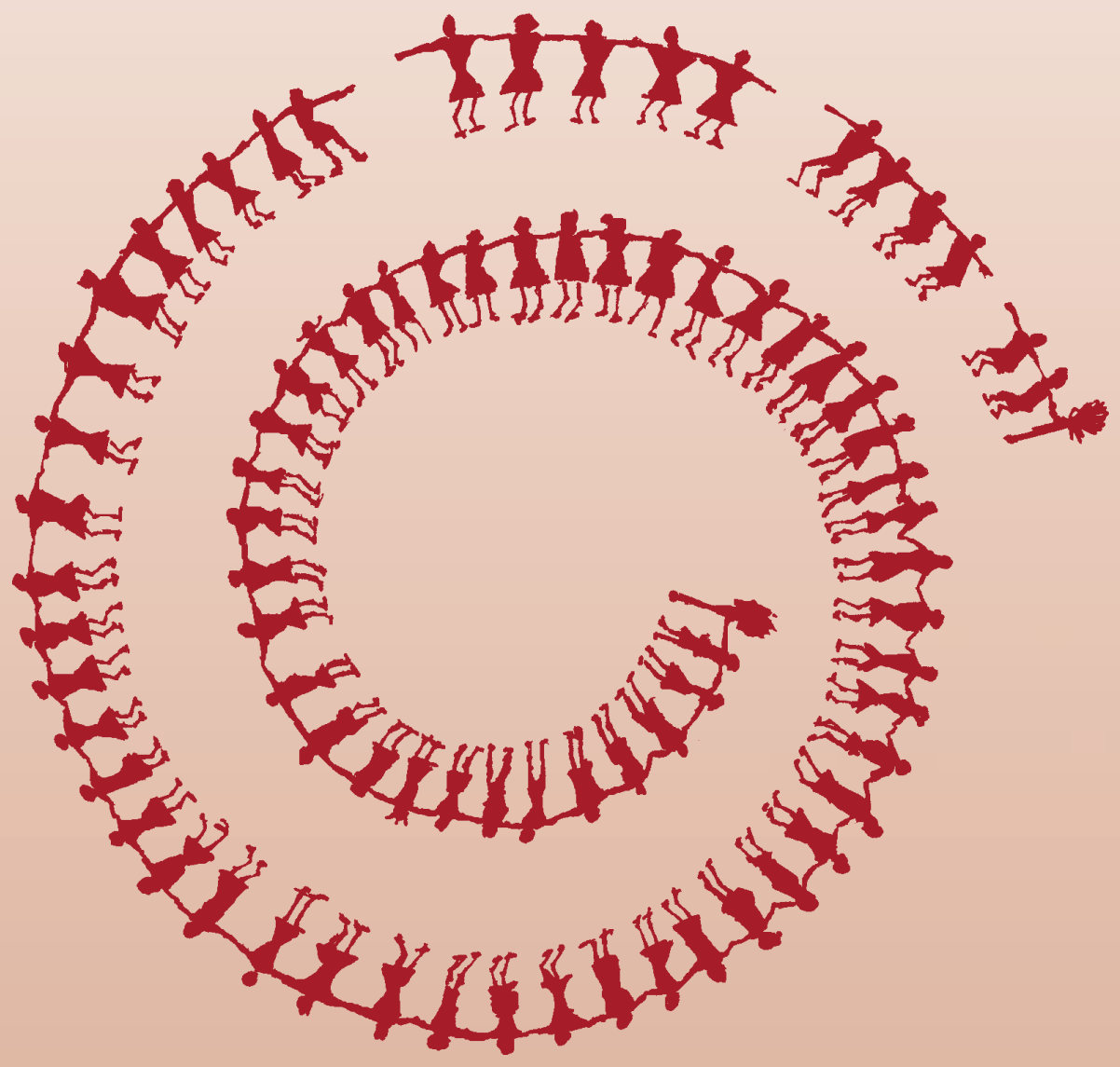




\section{Secondary Education in India}

\section{SASHD}

November, 2003

Human Development Sector South Asia Region

The World Bank 


\section{Table of Contents}

Executive Summary

I. Introduction

II. Policy Context

III. The Status of Secondary and Higher Secondary Education in the Country

IV. Issues in Secondary Education 


\section{ACKNOWLEDGMENTS}

This report was task managed and written by Prema Clarke. Keith Hinchliffe participated in the task during its early stages. The note is based on four commissioned pieces of research: (i) an analysis of national level data on secondary education done by Jyotsna Jha (an independent consultant); (ii) a more detailed analysis of State level secondary data on selected southern States undertaken by Manabi Majumdar (Madras Institute for Development Studies) and on selected Northern States by Jyotsna Jha; (iii) a review of literature in secondary education done by Anupam Ahuja (an independent consultant); and (iv) enrollment projections done by the late Yash Aggarwal (National Institute for Education Planning and Administration).

Renu Gupta assisted by providing valuable secretarial support for this task. Comments received from several individuals served to strengthen this report. The author is grateful to the peer reviewers (Sajitha Bashir, Tobias Linden, and Xiaoyan Liang) for their comments and also to others who provided feedback on the paper including Charles Griffin, Michelle Riboud, Ananya Basu and N.K. Jangira. 


\section{ABBREVIATIONS AND ACRONYMS}

CBSE

CISCE

COBSE

GER

GNP

GOI

HSE

ICT

IT

KVS

MHRD

NCERT

NCTE

NIEPA

NOS

NSSO

NVS

OECD

SC

SCERT

SE

SIEMAT

SSA

ST

TPR
Central Board of Secondary Education

Council for the Indian School Certificate Examinations

Council of Boards of Secondary Education in India

Gross Enrollment Ratio

Gross National Product

Government of India

Higher Secondary Education

Information and Communication Technologies

Information Technology

Kendriya Vidyalaya Sangathan

Ministry of Human Resource Development

National Council of Educational Research and Training

National Council for Teacher Education

National Institute of Educational Planning and Administration

National Open School

National Sample Survey Organization

Navodaya Vidyalaya Samiti

Organization for Economic Cooperation and Development

Scheduled Caste

State Council of Educational Research and Training

Secondary Education

State Institute for Educational Management, Administration and Training

Sarva Shiksha Abhiyan

Scheduled Tribe

Teacher Pupil Ratio 



\section{EXECUTIVE SUMMARY}

1. Secondary education is increasingly becoming an area of focus in developing countries, which have thus far concentrated on achieving universal elementary education. This policy note on secondary education in India discusses issues and aspects critical for the development of this subsector. Secondary education, in terms of policy, is a concurrent item in that it is within the purview of both State and Central governments. State level implications and strategies for developing this sub-sector are critical. The Central government involvement in secondary education thus far has been through discrete programs, such as computer and vocational education. The $10^{\text {th }}$ Five-Year Plan (2002-2007) intends a much more strategic role for the Central government in improving secondary education in the country. This policy note supports this national vision and highlights the issues and constraints in implementing this vision.

2. Secondary education includes two years of secondary (referred to as SE) and two years of higher secondary education (referred to as HSE). There are 28 million students enrolled in secondary and higher secondary education in the country, representing a Gross Enrollment Ratio (GER) of 35 percent. Two-thirds of those students enrolled in upper primary and a fourth of those enrolled in primary continue on into secondary. The GER for girls is 14 percent lower than that of boys indicating the need for focusing on girls' enrollment. There is considerable variation across States in terms of GERs and also in terms of differences in gender equity. Three types of schools provide SE and HSE in the country: government funded, private unaided and private aided [referred to in this Report as government, private and aided respectively]. The aided schools are privately owned, where teachers' salaries and other recurring expenditures are funded by State governments. Except for States where the aided sector is strong, the government involvement in SE and HSE is significant. The range in the share of aided schools across States is 54 to 99 percent. The share of private schools in SE is 13 percent and for HSE 18 percent. An average 60 percent of the students across States are successful in obtaining certification in government schools, portraying the critical need for improving educational quality.

3. The policy note concludes with a summary of issues and aspects critical for this sub-sector relating to four areas: planning in secondary and higher secondary education; administrative reform; improving the quality of education and financing of secondary education.

4. Planning in secondary and higher secondary education: Planning in secondary education is weak at both State and national levels. State level planning has so far involved the allocation of central funding and a continuation of activities from the previous year. Clearly, comprehensive State level planning for improving SE and HSE is important. The Central government, on the other hand, could nurture a far more strategic involvement with the States in improving this level of education, clearly envisioned within the Government of India's $10^{\text {th }}$ Five-Year Plan. Possible approaches for such strategic involvement could be to position itself within the States' comprehensive plans for secondary education reform, and focus on specific areas identified in the $10^{\text {th }}$ Plan such as equity, quality and so on. In this situation the Center would also develop a range of technical resources, which States could draw upon depending on the focus and needs defined in their plans.

5. Management and administrative reform: Four aspects can be identified here. Firstly, the many institutions involved in SE and HSE at the State level currently appear to be operating independent of each other. This is likely due to the absence of an overall vision for the sub-sector. Depending on how States' decide to position their SE and HSE sectors, it will be critical to focus on a more effective functioning of the institutions aligned with this vision. Secondly, in order to improve secondary education, reform in teacher management requires attention. An adequate number of 
teachers, transparent and effective transfer and deployment policies and systematic and focused professional development will reduce the constraints to improving secondary education. Thirdly, the States could explore support for the grant-in-aid system with adequate regulatory norms and monitoring mechanisms in place or the possibility of providing vouchers to students to attend private schools. Fourthly, in order to manage the sector more efficiently, it would be critical to put in place a computerized monitoring information system for significant indicators, such as enrollment and retention, in addition to an assessment system to provide data on student performance across districts and States.

6. Quality improvement: The performance of students portrays a critical need to improve the quality of instruction in both SE and HSE schools. Two options are available to State and Central governments. In the first option, quality improvement would take place within the current system, assuming that the students are being sufficiently prepared for the expectations of the labor market. In this case, the current curriculum and examination model would continue and infrastructure needs relevant to improving student performance within the existing model would be taken up. It will also be necessary to put in place a system for ensuring Teacher training in subject content knowledge and accountability for teachers and for schools. In the second scenario, the improvement of quality would be based on the assumption that the focus of secondary education is the development of lifelong learning skills, which would then involve a revamping of the whole system. Here, school improvement and teachers' professional development through reform in inservice and preservice training would be of paramount importance in addition to reforms in textbooks, curriculum and examinations.

7. Vocational education: This is an area that requires rethinking. The success of most of the States that have attempted to implement the Centrally sponsored scheme of vocational education has been limited, especially when the size of the investments made for vocational education is considered. In rethinking vocational education, the question of direct involvement of industry and employers needs to be addressed, and accordingly the proportionate focus on generic skills decided. If industry and employers are not willing to participate in providing vocational training, perhaps, providing all students with a generic set of skills could be a more appropriate option.

8. Financing: Thus far the focus, rightly so, has been on elementary education. Increasingly the importance of secondary education to the country's economic progress is becoming critical. If there is going to be a concerted effort at secondary education reform, the current level of funding is insufficient and unavailable for critical quality improvement in this sub-sector. While State level increase in financial allocation is critical, the need for clear incentives and performance indicators associated with Central allocations to States would be important. 


\section{INTRODUCTION}

1.1 Secondary education is at the threshold of gaining critical attention in India. This is so even as concerted efforts in elementary education across the country bring about expansion and increased aspirations for further good quality education. Internationally, secondary education has become important in the context of changing global labor markets and changes in the requirements of and emphasis on higher education. A workforce with an appropriately designed secondary education is also increasingly being considered as integral to the economic development of a country. The forces that have highlighted secondary education internationally are becoming more and more pronounced in India with the globalization of the economy and the advent of the age of information technology (IT). In this milieu, it was deemed fit to begin to understand this sub-sector and, therefore this work in secondary education was undertaken. While this note is primarily meant for a Bank audience, it is also intended to begin dialogues with the national and State governments on developing this sub-sector.

1.2 This policy note on secondary education in India, begins with an introduction to its policy context, followed by an examination of the status of this sub-sector. This is followed by a discussion of the issues in secondary education. The conclusion highlights specific areas requiring attention in this sub-sector. The policy note is based on secondary data available at the national level, a few commissioned analyses of secondary data in selected States (Andhra Pradesh, Assam, Kerala, Maharashtra, Orissa, Rajasthan, Tamil Nadu and Uttar Pradesh) and a literature review of studies in secondary education over the last decade. ${ }^{1}$

\section{POLICY CONTEXT}

2.1 Historically, Universities controlled secondary education in India until 1917. In 1917, with the formation of an independent Board of Education to control high schools, secondary schooling became "an independent sub-sector" in the country. ${ }^{2}$ The 1952 Secondary Education Commission introduced the policy of developing a three-year national system of secondary education (after eight years of elementary education). The four-year secondary education system was first recommended by the 1964 Kothari Commission and reiterated in the 1986 National Policy on Education. The National Policy on Education and Program of Action (1992) for its implementation advocated uniformity across States in the expansion of secondary education. This stage of education was also emphasized as an instrument for social change.

2.2 The federal structure in the country has a considerable impact on all aspects of secondary education. The policy context of secondary education in India is influenced by the inclusion of education on the concurrent list since 1976, making it the responsibility of both the Central and State governments. Unlike elementary and higher education, the respective responsibilities of State and Center are not as clearly defined for secondary education. ${ }^{3}$ The role of the Center is usually contained in the FiveYear Plans put forward by the Government of India (GOI). Until the $9^{\text {th }}$ Five-Year Plan the

\footnotetext{
${ }^{1}$ The following sources were also used: (i) Sixth All-India Educational Survey 1993 (NCERT 1998); (ii) Selected Educational Statistics (Different Years) MHRD, GOI; (iii) Education in India (1994-95), MHRD, GOI, 2001; (iv) National Family Health Survey (II), International Institute of Population Sciences, 2000; (v) A Handbook of School Education and Allied Statistics (1996), MHRD, GOI; (vi) Annual Report (different years), MHRD, GOI; (vii) National Sample Survey Reports (50 th $52^{\text {nd }}$ and $55^{\text {th }}$ Round); (viii) Selected Information on School Education in India, 1996-97, (MHRD, 2000).

${ }^{2}$ The Sargeant Report 1944 set in place the five year schemes and recommended that High school covers a period of six years, and two streams, academic and technical, not restricted by university demands; entry to high schools was to be on a selective basis.

${ }^{3}$ Except in the case of the Union Territories. According to the MHRD 00-01 report on secondary education the Central government has a special responsibility to oversee education in the Union Territories.
} 
involvement of the Center in secondary education was confined to the support given to apex national level institutions and a few Centrally sponsored schemes (CSS). Apex level institutions such as the National Council of Education Research and Training (NCERT) and the National Institute for Educational Planning and Administration (NIEPA) provide support to the States and set guidelines for secondary education, especially in the area of curriculum.

2.3 There is continuity in the areas of focus in the CSS in the Five-Year Plans, though, for the most part the areas chosen for funding appear to be fragmented rather than integrated and targeted to support secondary education. Thus far, the main CSS in secondary education is the national program, on Vocationalisation of Secondary Education introduced in 1988. The objective of this program was to ensure that 25 percent of the secondary school students opt for vocational education courses. Central funding is also available to the States for improving science education and for the program entitled Computer Literacy and Studies in Schools, which introduces computers in schools. Other national schemes include Kendriya Vidyalaya (1965) and Navodaya Vidyalaya (1985). The Kendriya Vidyalya schools are for the children of transferable Central government employees and Navodaya Vidyalaya schools are for gifted students from rural areas. ${ }^{4}$

2.4 The current Five-Year Plan suggests a more significant role for the Central government in secondary education in the States. The 10 ${ }^{\text {th }}$ Five-Year Plan (2002-2007) assigns a more "strategic and focused" role for the Center in secondary education..$^{5}$ According to the Report of the Working Group on Secondary Education for the $10^{\text {th }}$ Five-Year Plan (2002-07) "[the Center] may also share with the States the responsibility of giving direction to the expansion and qualitative improvement [of secondary education (SE) and higher secondary education (HSE)]." This report suggests that the Center could provide support to the States in the areas of "access and equity; quality improvement; information and communication technologies (ICT); integrated/inclusive education for the disabled and other disadvantaged groups; and vocational education." Clearly, the way in which GOI operationalizes this intention will impact improvement in secondary education in the States.

2.5 The national curriculum outlines the objectives for education at this level. The overall 23 objectives of education, which cover a range of skills, values and attitudes are outlined in the National Curriculum for elementary and secondary education. The objectives include the development of basic skills in language, communication, mathematics, science and environmental studies. Contextualized knowledge is important and the values to be inculcated include national pride, an appreciation of the history and cultural diversity of India, an awareness of social and economic issues, and the development of personal and spiritual values. Interestingly, the ability to reason and to analyze situations and information is not clearly highlighted in the objectives for secondary education, though it could be embedded in this objective of developing the "ability not only to accumulate factual information but also to understand, reflect and internalize and develop insight (NCERT, 1999)." In sum, the goals for secondary education are to develop responsible citizens and leaders in the community. Though the National Curriculum refers to national norms, it has not been possible to ascertain the extent to which States have adopted these norms or alternatively have redefined or incorporated these objectives into the State's goals for education.

\footnotetext{
${ }^{4}$ Kendriya Vidyalaya schools were established with the main purpose of providing uninterrupted schooling facilities with a common syllabus and medium of instruction to children of transferable employees of the central government. In 1985-86, the Government of India launched a scheme called Navodaya Vidyalaya, a residential school program in each district with the aim of providing 'quality modern education' to children in rural areas. The 480 schools (with total enrollment of 125,000 students) are fully subsidized by the Central government and managed by an autonomous body (Navodaya Vidyalaya Samiti) set up by the Central government. These schools start from Grade 6 and run up to Grade 12. The school caters to students from disadvantaged backgrounds, though only a few students come from poor families. Since these two schemes are relatively small, they will not be dealt with at length in this paper.

${ }^{5}$ The 10th Five Year Plan is based on several assumptions, two of those being a GDP growth of 8-10 percent and doubling of per capita income by 2010 and quadrupling it by 2020.
} 
2.6 Information is not easily available on the policy contexts in States and it is unclear except for a few whether they are involved in strategic thinking about this sub-sector. Correspondingly, how the inclusion of Centrally sponsored schemes or Central support for specific programs fits into overall State plans for secondary education is not evident. In other words, the issue here is whether States are developing secondary education in a holistic manner with specific objectives or whether attention to secondary education is only undertaken within the context of programs that receive Central assistance. Karnataka is one State that has embarked on a systematic analysis of this level of education and is in the process of putting together a plan for comprehensive reform in this subsector (World Bank Report No. 24208-IN) that incorporates a State vision and funding for secondary education as well as Central programs and financial assistance. Improving the quality of secondary education in government schools is a significant goal for the Government of Karnataka and policies to enable this to happen are being put in place.

2.7 To summarize the above discussion, the Center and State are both involved in secondary education in the country. The Center has thus far been involved in education through apex level institutions, setting in place guidelines for secondary education and through a few Centrally sponsored schemes. The Center intends to play a much more significant role in secondary education and the way this intention is operationalized will be important. It is unclear whether State level strategic policy planning critical to secondary education reform is in place. This paper highlights the importance of strategic planning at the State level and the incorporation of Central funding into these plans. The national curricular guidelines outlining the objectives for this level gives minimum emphasis to the skills of reasoning and analysis crucial for preparing students to be lifelong learners. Considering the opportunities for students certified with SE and HSE, an option for the national level and for the States is to enact policies and programs that will nurture and develop these skills discussed in more detail later in this note. In order to be able to discuss issues in secondary education more effectively, the following section examines the basic status of SE and HSE in India.

\section{STATUS OF SECONDARY AND HIGHER SECONDARY EDUCATION IN THE COUNTRY:}

3.1 The status of secondary education briefly introduces the structure of this level of education, the patterns of enrollment, retention and transition, the vocational component and finally, the financing of secondary education in the country.

\section{A. Structure}

3.2 Secondary (Table 1) is divided into two stages, lower or junior secondary (to be referred to as secondary in this paper) and senior or higher secondary. Secondary education is varied and depends on whether States have adopted the national structure for elementary education of eight years duration. Excluding the Union Territories, about nine States continue to have seven years of elementary education, making secondary three years rather than two as in the other States. Nagaland, unlike the rest of the States in India, has six years of elementary and four years of secondary education. It is unclear whether States with a three-year secondary education program are in transition and will adopt the national structure in the next few years. In general, there are no subject choices to be made by students in SE, the curriculum is standardized depending on the certification process described below. Higher secondary education, consisting of two years, is uniform across the country. Higher secondary, different from secondary education, offers a choice of curriculum to students and the main streams are Humanities, Science and Commerce. While in the majority of States higher secondary education is part of school education, in some of the States, the situation is far more complex with universities in addition to schools being involved in higher 
Table 1: SE and HSE structure and HSE affiliation

\begin{tabular}{|c|c|c|c|}
\hline State & $\begin{array}{l}\text { Number of Grades } \\
\text { for elementary, } \\
\text { SE and HSE }\end{array}$ & $\begin{array}{l}10+2 \text { system } \\
\text { adopted in year }\end{array}$ & Affiliation of HSE \\
\hline Nagaland & $(6+4)+2$ & - & School/University \\
\hline Arunachal Pradesh & $(8+2)+2$ & 1978-79 & School \\
\hline Haryana & $(8+2)+2$ & 1985 & School \\
\hline Himachal Pradesh & $(8+2)+2$ & 1986 & School \\
\hline Jammu \& Kashmir & $(8+2)+2$ & - & School \\
\hline Madhya Pradesh & $(8+2)+2$ & $1985-86$ & School \\
\hline Manipur & $(8+2)+2$ & $1974-75$ & School \\
\hline Punjab & $(8+2)+2$ & $1986-87$ & School \\
\hline Rajasthan & $(8+2)+2$ & $1988-89$ & School \\
\hline Sikkim & $(8+2)+2$ & 1975 & School \\
\hline Tamilnadu & $(8+2)+2$ & 1978-79 & School \\
\hline Tripura & $(8+2)+2$ & $1978-79$ & School \\
\hline West Bengal & $(8+2)+2$ & 1976 & School \\
\hline Bihar & $(8+2)+2$ & 1978-79 & School/University \\
\hline Karnataka & $(8+2)+2$ & & $\begin{array}{l}\text { School/Pre- } \\
\text { University }\end{array}$ \\
\hline Uttar Pradesh & $(8+2)+2$ & $1987-88$ & $\begin{array}{l}\text { School/Pre- } \\
\text { University }\end{array}$ \\
\hline Andhra Pradesh & $(7+3)+2$ & & School/University \\
\hline Orissa & $(7+3)+2$ & $1979-80$ & School/University \\
\hline Assam & $(7+3)+2$ & - & School/University \\
\hline Kerala & $(7+3)+2$ & 1990-91 & School/University \\
\hline Maharashtra & $(7+3)+2$ & 1975 & School/University \\
\hline Mizoram & $(7+3)+2$ & & School/University \\
\hline Goa & $(7+3)+2$ & 1975 & School \\
\hline Gujarat & $(7+3)+2$ & 1986 & School \\
\hline Meghalaya & $(7+3)+2$ & $1994-95$ & School \\
\hline
\end{tabular}

Source: Education in India, MHRD, Government of India, 2001

secondary education. Universities also offer higher secondary education in eight States. ${ }^{6}$ In Karnataka and Uttar Pradesh, separate institutions (pre-university or junior colleges) affiliated to university education are also responsible for this level of education. The diversity in the affiliations of higher secondary clearly raises issues related to the administration and financing of secondary education.

\footnotetext{
${ }^{6}$ The eight States are Nagaland, Bihar, Andhra Pradesh, Orissa, Assam, Kerala, Maharastra and Mizoram.
} 


\section{B. Enrollment}

3.3 There are 28 million students enrolled in secondary and higher secondary education in the country representing a Gross Enrollment Ratio (GER) of 35 percent. Two thirds of those students enrolled in upper primary and a fourth of those enrolled in primary continue on into secondary (Figure 1). The median growth rate in secondary (6.45) is higher than in upper primary (5.61) and primary (3.95). Though the rate of increase in secondary is higher than in upper primary and primary, the recent increase in primary enrollment is not reflected yet in the enrollment in upper primary and secondary education. It is likely that this increase will take place over the next few years, which has both policy and financial implications discussed later in the paper. In terms of the proportion of boys to girls over the last few decades, enrollment has improved from 13 percent to 38 percent. However, the GERs reflect a continued gender gap for boys and girls. The GER for boys is 42 percent and that for girls, 28 percent. Net Enrollment Ratios are not available. If the increase in enrollment is considered over the last 50 years, except during the last decade, enrollment appears to have almost doubled each decade. In the last ten years, enrollment has increased by about 30 percent. During this period, girls' enrollment has increased more than that of boys -55 times for girls and 13 times for boys. However, the gap between boys and girls' enrollment continues to be large.

3.4 Certain populations in India have traditionally been disadvantaged and these communities are officially referred to as Scheduled Caste (SC) and Scheduled Tribes (ST). The proportion of SC and ST students is much less than their share of the population. In 1999, SC enrollment represented seven percent of the total enrollment in secondary, whereas their share in the population is 14 percent. The situation was worse in senior secondary where only two percent were enrolled. Similarly with the ST community, which constitutes about eight percent of the population, 2.6 percent of the students were enrolled in secondary and 0.8 percent in senior secondary. Within these groups, the small percentage share of girls' enrollment is also a concern. The low representation of SC and ST students in SE and HSE does highlight the issue of equity that needs to be addressed. SE and HSE graduates among the minority population are also low. Taking economic levels into consideration, only 20 percent of students from the lowest income quintile are enrolled in SE and HSE (World Bank 2002b). Thus caste and income inequity in secondary education will need to be addressed.

3.5 State variations in enrollments and GERs are evident (Table 2). For both boys and girls, Himachal Pradesh, Gujarat, Kerala, Tamil Nadu, and Maharashtra represent States with higher enrollment (range here is 30 to 54 percent). While the enrollment for boys is fairly high in Madhya Pradesh (44 percent), the State has not done well with girls' enrollment (21 percent). Girls' GERs in Uttar Pradesh, Rajasthan and Orissa are low (14 to 16 percent) and in Bihar particularly low (under 10 percent). While the difference between GERs of girls and boys range between 1 to 17 percent in most of the States, in Madhya Pradesh, Uttar Pradesh and Rajasthan the difference is over 20 percentage points. In a national program of secondary education, the regional variations indicate 
Table 2: State Gross Enrollment Ratios

\begin{tabular}{|lccr|}
\hline & Girls & Boys & Differential \\
\hline Andhra Pradesh & 22.92 & 36.99 & 14.07 \\
\hline Assam & 28.96 & 39.56 & 10.6 \\
\hline Bihar & 8.82 & 20.96 & 12.14 \\
\hline Gujarat & 31.36 & 40.67 & 9.31 \\
\hline Haryana & 23.57 & 33.05 & 9.48 \\
\hline Himachal Pradesh & 37.89 & 54.09 & 16.2 \\
\hline Jammu \& Kashmir & 26.89 & 33.39 & 6.5 \\
\hline Karnataka & 29.17 & 40.48 & 11.31 \\
\hline Kerala & 43.05 & 41.67 & -1.38 \\
\hline Madhya Pradesh & 21.24 & 44.87 & 23.63 \\
\hline Maharashtra & 34.72 & 46.38 & 11.66 \\
\hline Orissa & 14.31 & 31.64 & 17.33 \\
\hline Punjab & 30.74 & 35.93 & 5.19 \\
\hline Rajasthan & 13.62 & 37.86 & 24.24 \\
\hline Tamilnadu & 34.88 & 49.64 & 14.76 \\
\hline Uttar Pradesh & 15.64 & 38.99 & 23.35 \\
\hline West Bengal & 19.91 & 30.66 & 10.75 \\
\hline
\end{tabular}

Source: Calculated on the basis of provisional enrollment figures provided in Selected Educational Statistics 1999-2000, and estimated population size for 14-17 years.

the necessity for adopting different strategies that address each State's distinctive issues and contexts in any program of reform in the sub-sector. In addition, it indicates the need for States to define the role and size of secondary education according to its needs and within an overall plan to develop education in the State.

3.6 In those States where universities offer HSE, 25 percent of the enrollment in higher secondary is in colleges or universities and thus not a part of school education. In terms of subject choices in higher secondary education, only 1993 data is available. Humanities or the arts is the most popular with 48 percent of the students (53 percent girls) opting for this stream, followed by Science with 28 percent (23 percent for girls). More students opting for the Humanities rather than the Science stream is intriguing and must be a response to both the limitations of elementary education and students' perceptions of their inability to master science subjects. It is likely that instruction in the sciences are weak. This difference in enrollment between the Humanities and the Science streams was exacerbated when rural and urban locations were considered - more rural students (59 percent) opted for Humanities than the urban students (41 percent). After Humanities and Science, Commerce, Agriculture and Vocational Education streams were the other choices for higher secondary students. Enrollment patterns in the different streams and the quality of science instruction especially in rural schools are areas of concern for development of this level of education.

3.7 Three types of institutions - private, aided and government schools - capture overall enrollment in SE and HSE. ${ }^{7}$ Government schools are fully financed by either Central or State governments

\footnotetext{
${ }^{7}$ Within the government sector itself both State and local governments are responsible for education. Local governments could include those at the district or Panchayat level or the municipalities, which are local governments in urban areas. In addition, there are providers specific to a certain State. For example, in Andhra Pradesh there is a society known as the AP Residential Educational Institutions Society responsible for residential schools. In Maharastra, the Social Welfare Department runs Ashram schools in the State. It is not known how large these providers are since they are included within the category of "government."
} 


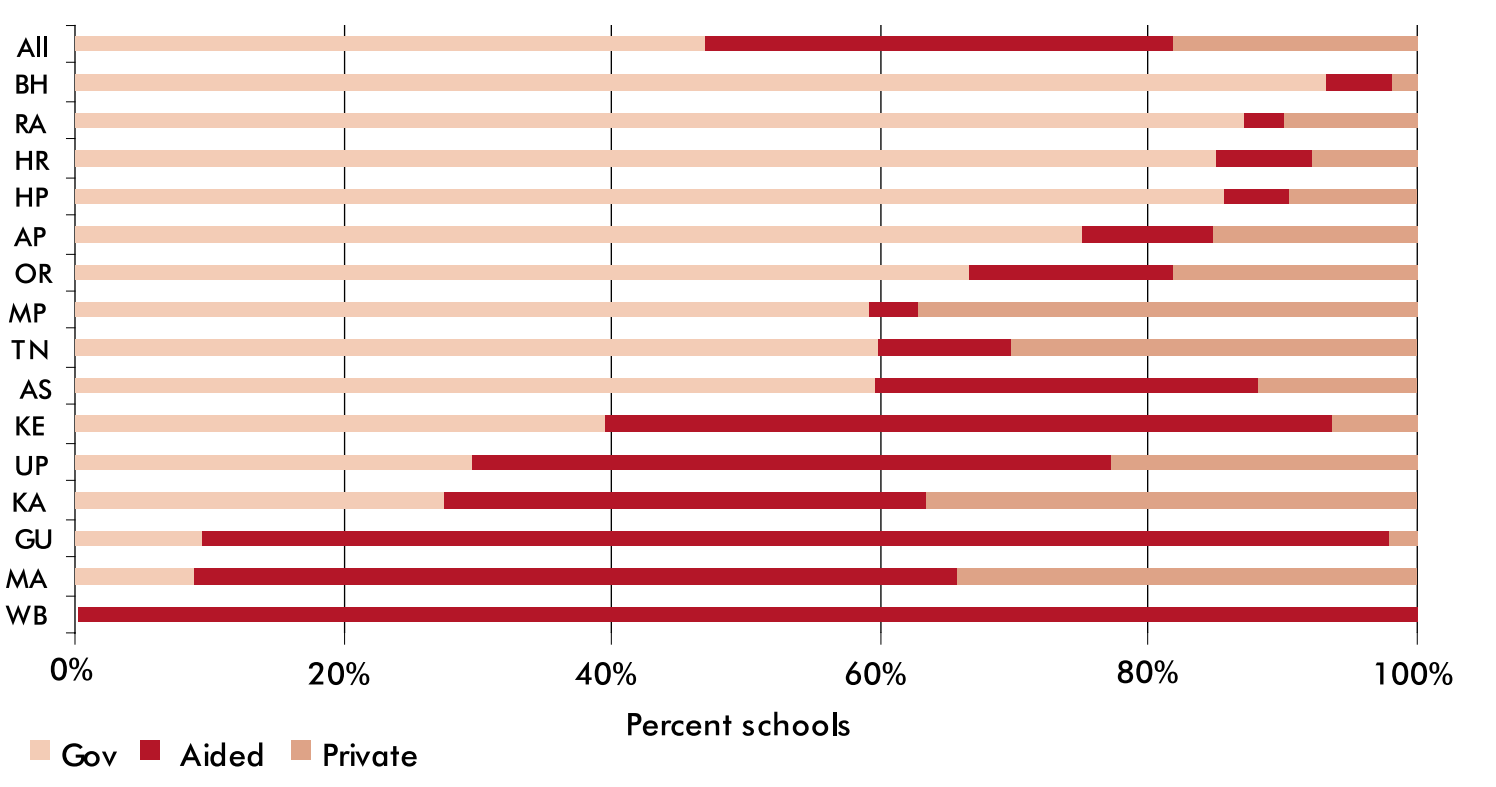

Source: Education in India, MHRD, Government of India, 2001

and in States managed by either government or local bodies. In most government schools, the medium of instruction is the State language with English as a second language. Aided schools are managed privately by individuals, trusts, societies or corporate bodies but funded largely by government. The government is responsible for the entire recurring costs for these schools while the management is responsible, fully or partially, for the physical facilities and administration. The

\section{Figure 3: Higher secondary school distribution by management}

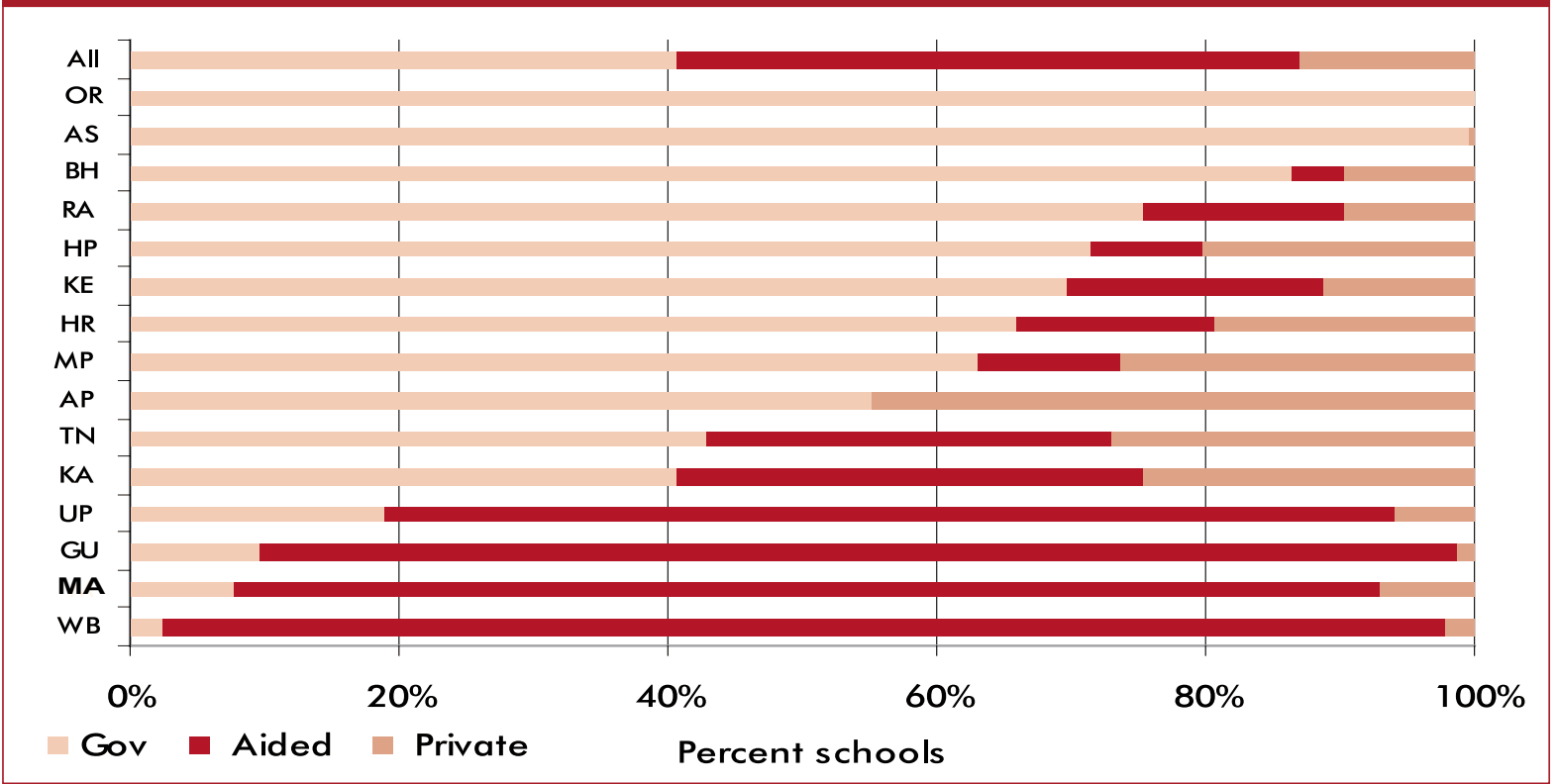

Source: Education in India, MHRD, Government of India, 2001

${ }^{8}$ There are different ways in which a school can be aided. It can receive government support when it starts functioning or it can receive support after a few years of being independent. In the latter case, the schools receive incrementally higher levels of funding over the years. 
medium of instruction could be English or the local language. The aided schools are an important way in which the government makes use of the private sector to provide education. ${ }^{8}$ The private schools are mainly English medium and managed and financed privately. The question of the number of schools that fall into each of these categories within States has considerable implications for the financing and administration of secondary education.

3.8 The share of the three types of schools varies across States (Figure 2 and 3). ${ }^{9}$ Except for the States in which the aided schools are strong, government involvement in SE and HSE is fairly substantial. The share of private schools for secondary (18 percent) is higher than that for higher secondary (13 percent), and this could possibly be due to the share of higher secondary that is part of university education, which is not accounted for in these figures. In secondary education in Madhya Pradesh, Maharastra and Karnataka, the private share is over 30 percent followed by Tamil Nadu and Uttar Pradesh. In higher secondary, Andhra Pradesh has the highest proportion of private secondary schools (44 percent), followed by Haryana, Madhya Pradesh, Karnataka and Tamil Nadu with over 20 percent.

3.9 For reasons that are perhaps, historical and political, in four States - Uttar Pradesh, Gujarat, Maharastra, and West Bengal for HSE and West Bengal and Gujarat for SE - the share of aided schools is the largest, accounting for over 50 percent (54 to 99 percent) of schools in these States. Taking SE and HSE together for the country, aided schools account for 35 percent. Compared to primary schools where the aided sector is weak in rural areas, the aided sector in SE and HSE in a few States is quite strong in rural areas. While aided schools account for the highest proportion

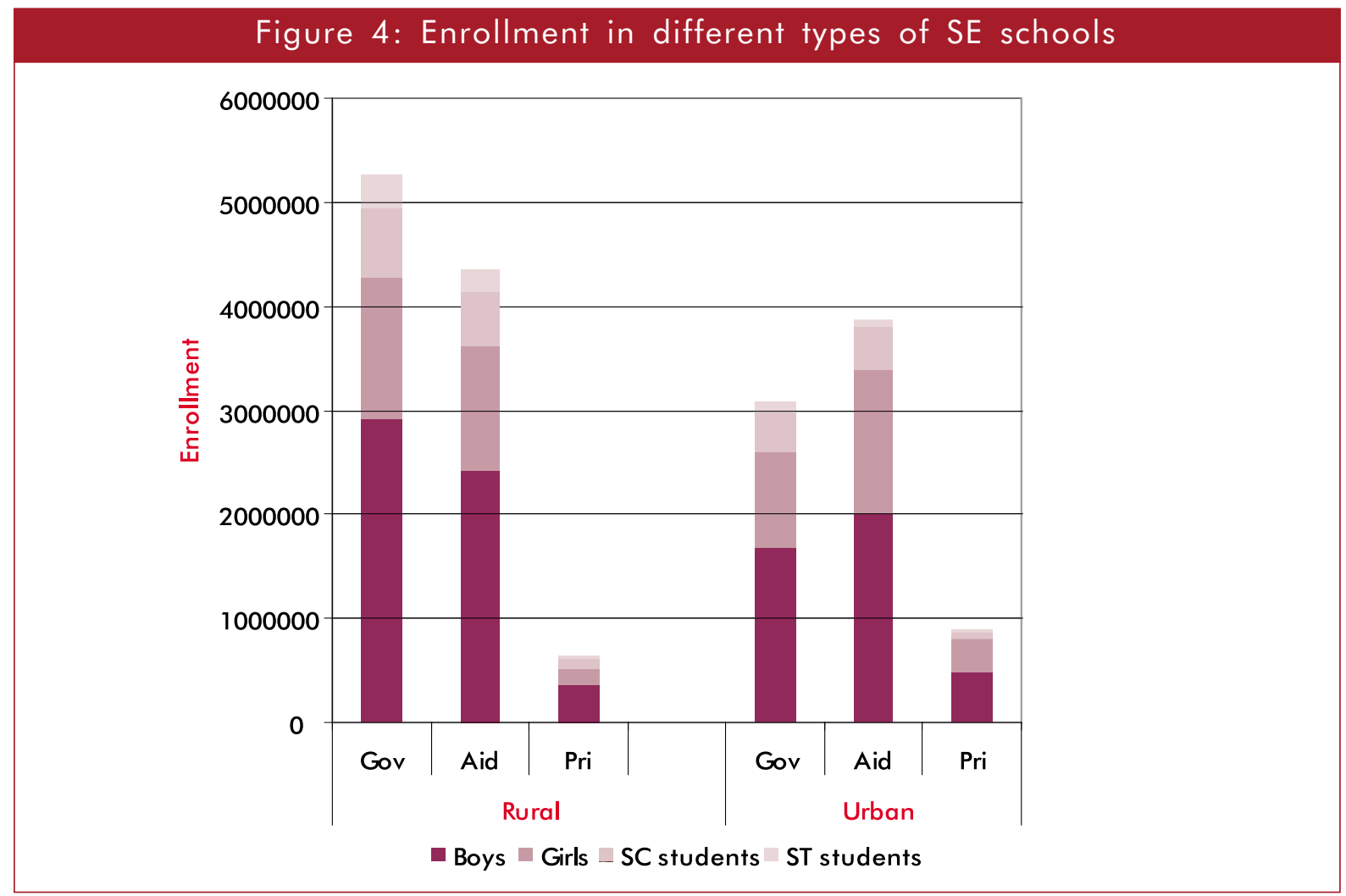

Source: Sixth All-India Educational Survey (NCERT, 1993)

\footnotetext{
${ }^{9}$ While there is recent data available on the number of institutions falling into the three categories — private, aided and public - at the national level, data on student enrollment in the three types of institutions is only available from the NCERT 1993 survey.
} 


\section{Figure 5: Enrollment in different types of HSE schools}

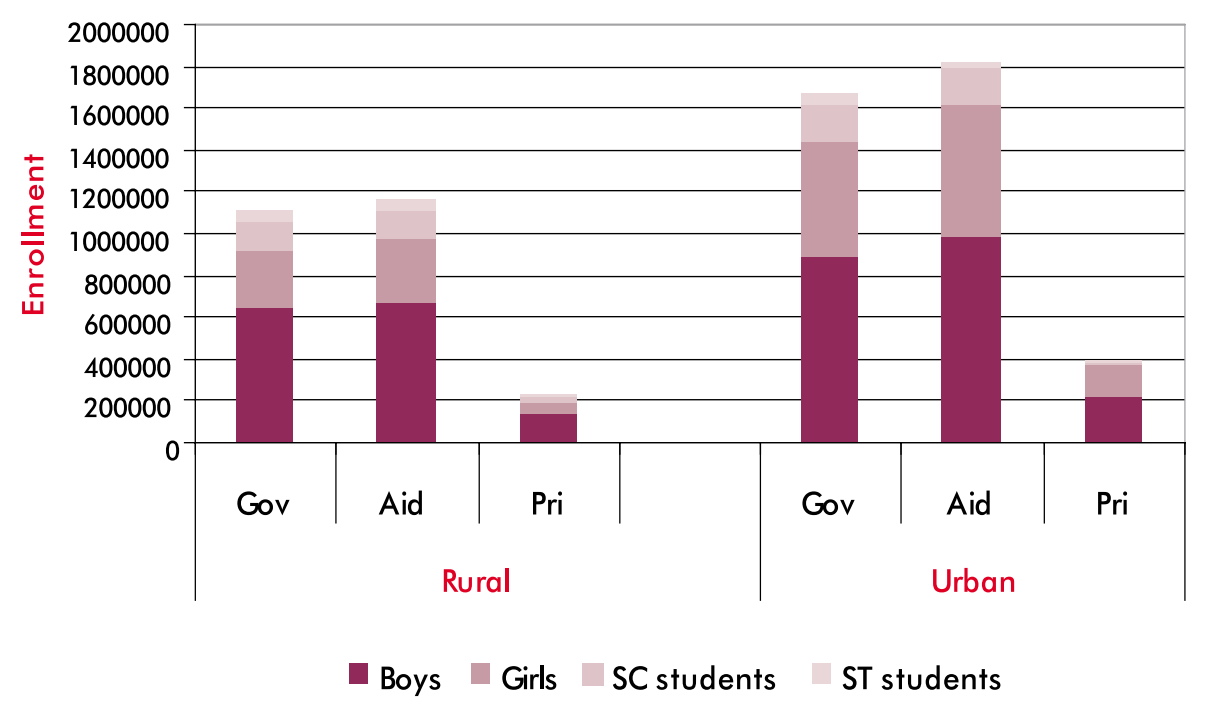

Source: Sixth All-India Educational Survey (NCERT, 1993)

of students at this level, there has been an increase of 13 percent in enrollment in government schools between 1993-96 and a corresponding decrease in the aided schools reflecting the decline in support for aided schools across States. Girls' enrollment is comparable to boys' enrollment

\begin{tabular}{|c|c|c|c|c|c|c|c|}
\hline & $\begin{array}{l}\% \text { in SE } \\
\text { from UP }\end{array}$ & $\begin{array}{c}\% \text { in } \mathrm{HSE} \\
\text { from } \mathrm{SE}\end{array}$ & $\begin{array}{c}\% \text { in } 10 \\
\text { from } 9\end{array}$ & $\begin{array}{c}\% \text { in } 11 \\
\text { from } 10^{\#}\end{array}$ & $\begin{array}{l}\% \text { in } 12 \\
\text { from } 11\end{array}$ & $\begin{array}{l}\text { Drop- } \\
\text { out* }\end{array}$ & $\begin{array}{c}\text { Repea- } \\
\text { ters* }\end{array}$ \\
\hline Andhra Pradesh & 43 & 70 & 87 & & 97 & 77 & \\
\hline Assam & 37 & 56 & 85 & & 85 & 76 & 10.11 \\
\hline Bihar & 42 & 36 & 86 & & 209 & 83 & .9 \\
\hline Gujarat & 47 & 46 & 81 & 57 & 80 & 72 & 2.02 \\
\hline Haryana & 51 & 60 & 95 & 70 & 77 & 50 & 15.53 \\
\hline Himachal Pradesh & 50 & 56 & 105 & 65 & 69 & 42 & 12.4 \\
\hline Jammu \& Kashmir & 40 & 38 & 73 & 43 & 104 & 65 & \\
\hline Karnataka & 40 & 96 & 88 & 108 & 88 & 68 & 4.0 \\
\hline Kerala & 58 & 27 & 80 & & 80 & 24 & \\
\hline Madhya Pradesh & 35 & 60 & 99 & 61 & 96 & 66 & 3.97 \\
\hline Maharashtra & 44 & 45 & 77 & & 92 & 59 & 3.58 \\
\hline Orissa & 45 & 68 & 89 & & 100 & 52 & 2.21 \\
\hline Punjab & 56 & 48 & 106 & 47 & 96 & 42 & 6.08 \\
\hline Rajasthan & 23 & 51 & 66 & 65 & 96 & 79 & 7.71 \\
\hline Tamilnadu & 45 & 46 & 97 & 51 & 81 & 58 & 6.5 \\
\hline Uttar Pradesh & 48 & 40 & 96 & 39 & 110 & 61 & 12.6 \\
\hline West Bengal & 38 & 50 & 73 & 63 & 86 & 82 & \\
\hline
\end{tabular}

Source: Selected Educational Statistics 1999-2000; Annual Report 1999-2000

\#blank spaces are States that have large enrollment in colleges for which information is unavailable

*for Grades I-X 
Table 4: Per 1000 distribution of 'dropouts' among ever enrolled but currently not attending (age 5-24 years) by level at which dropped out

\begin{tabular}{|c|c|c|c|c|}
\hline \multirow[t]{2}{*}{ Level } & \multicolumn{2}{|c|}{ Rural } & \multicolumn{2}{|c|}{ Urban } \\
\hline & Male & Female & Male & Female \\
\hline Primary & 304 & 369 & 224 & 219 \\
\hline Middle & 274 & 264 & 238 & 246 \\
\hline Secondary & 287 & 245 & 340 & 338 \\
\hline H Secondary & 78 & 61 & 111 & 105 \\
\hline Higher edu. & 27 & 14 & 65 & 70 \\
\hline
\end{tabular}

Source; NSSO 52 $2^{\text {nd }}$ round 1995-96

more in urban than in rural areas. Representation of SC and to a lesser extent, ST students (Figure 4 and 5) across different types of institutions is evident though in very small numbers and more in rural areas.

\section{Retention and Transition}

3.10 The information on retention, repetition and transition in SE and HSE is very limited. Due to the paucity of data, crude retention levels have been calculated (Table 3) based on the number enrolled in a particular year as a percent of those enrolled in the previous year. With the exception of Rajasthan, the range for enrollment in secondary education as a proportion of upper primary ranges from 35 to 58 percent across States. The transition from upper primary to secondary for Rajasthan is particularly weak (23 percent). Excluding Kerala, there appears to be a higher transition from SE into HSE, (the range is 36 to 96 percent) and from Grade 11 to 12 (over 70 percent).

3.11 Interestingly, Kerala's transition rate from secondary to higher secondary is alarmingly low at 27 percent. Possible causes for this dropout could be the low quality of secondary education in Kerala or the policy of automatic promotion, which allows students to move up the grades without passing an examination. Without examinations to test learning, students transit from grade to grade easily. However, when they have to face certification examinations, they tend to drop out of the system. Having said this, the Kerala picture communicated by the data is confusing. For example, Kerala has the lowest dropout here at 24 percent but the transition rate from upper primary to secondary is only 58 percent and from SE to HSE 27 percent.

3.12 Over 100 percent retention in Grades 10 through 12 suggests that students are enrolling after a break of a few years, or immigrating into the State from other States. ${ }^{10}$ In fact if one considers the number of students who appear for the certification examinations, 21 percent are not regular students. Some of these students enroll in schools just before the examinations. This phenomenon does reflect the inefficiency of the system, though it could also be taken as a symbol of student persistence in procuring SE and HSE certification.

3.13 The National Sample Survey Organization (NSSO) $52^{\text {nd }}$ Round (Table 4) provides comparative data on dropout across levels. The levels of dropout appears to be fairly close across Grades I to $\mathrm{X}$ and reduced in higher secondary. Within secondary, dropout is relatively higher in the urban areas than in the rural areas, possibly indicating greater opportunities for work in urban areas. Repetition rates on the average (Table 3 ) are around 5 percent, which is not high especially when compared to the rate of failure in examinations discussed below. This suggests that, as is the case

\footnotetext{
${ }^{10}$ The figure in lower grades could indicate movement from unrecognized to recognized schools. However, in secondary and higher secondary, because Board exams are involved and all schools have to be recognized, this is unlikely.
} 
with Kerala, students are in essence pushed through the system and then at the end are unsuccessful in the final examinations.

\section{Student Performance}

3.14 The certification process in all States in India is based on "public examinations" that have to be cleared at Grade 10 for secondary education and Grade 12 for higher secondary. Public examinations at the State level are offered by what are called "Boards of Education," which essentially certify students in their respective State. ${ }^{11}$ The Board in one State is independent of Boards in other States. In some States, the Boards are common for both SE and HSE; in others, each level has a

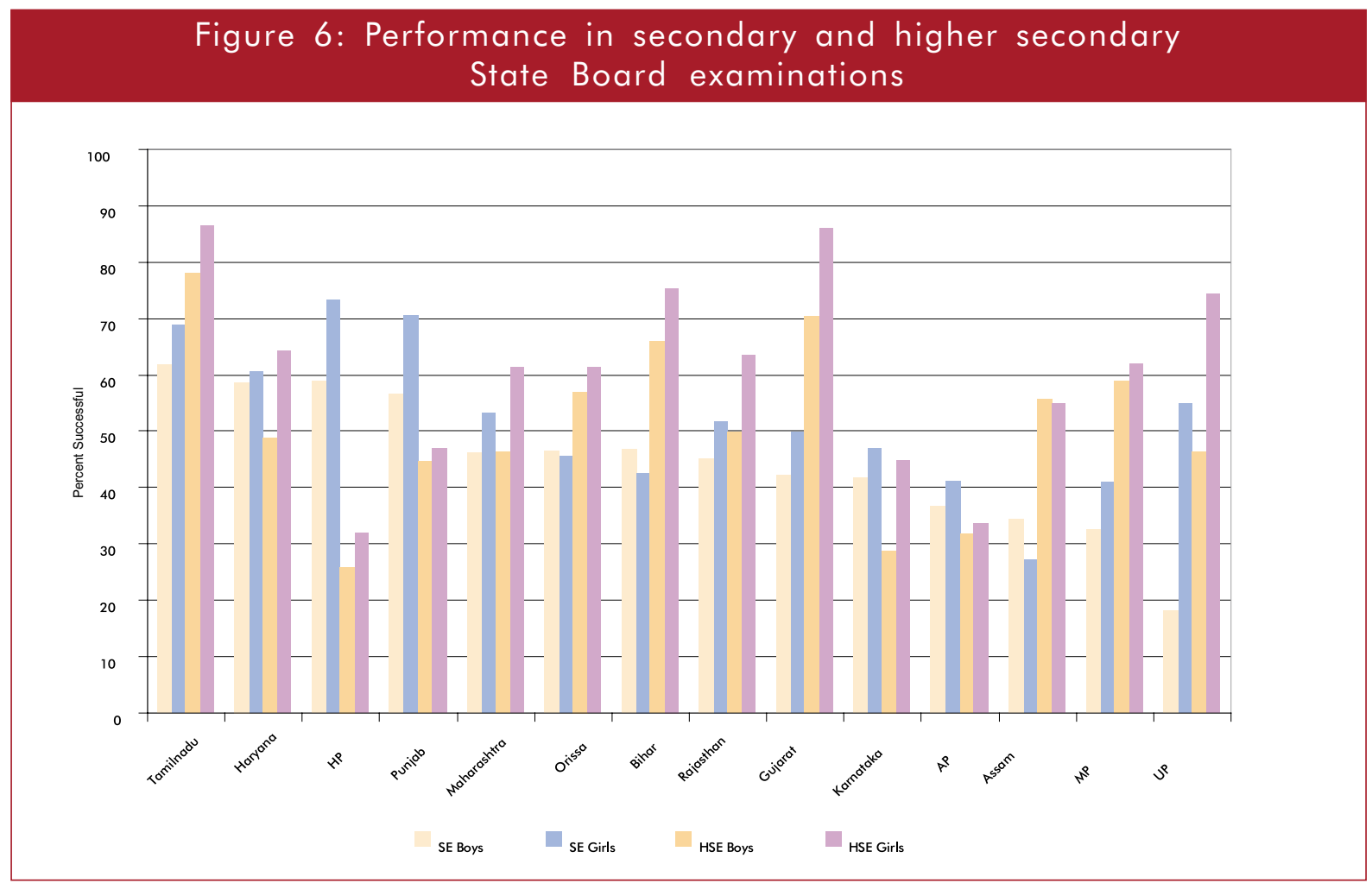

Source: Results of High School and Higher Secondary Examinations 1997 \& 1998, MHRD, Government of India, 2000

separate Board. The way in which these Boards are set up and their respective roles and responsibilities vary across States. In most States, the Boards are statutory autonomous bodies established through an Act of State legislature. In four States- Andhra Pradesh, Karnataka, Kerala and Tamil Nadu - the Boards are dependent organizations located within departments of education. It is not clear whether autonomy allows Boards to function differently or more effectively from those Boards that are not autonomous.

3.15 Grade 10 examinations are in many States the second public examination for students who have had to pass a public exam at the end of elementary school. Students have to obtain 33 percent marks in each subject and 35 percent in the aggregate to be successful in the examination, which indicates that they only have to know a third of the curriculum in order to pass. Except in Rajasthan and Tamil Nadu,

\footnotetext{
${ }^{11}$ The Council of Boards of Secondary Education (COBSE) was set up in 1979 to enable links between the different State examination Boards in the country. Though COBSE grants recognition to Boards and is involved in encouraging States to reform the examination system, the success of this organization is limited mainly because States are not responsive to Central suggestions and there are no incentives in place to encourage receptiveness to reform.
} 
certification is based solely on the performance of students in the final examination. In Rajasthan and Tamil Nadu, a small percent of the final grade is based on internal evaluation. However, internal evaluation is still based on performance in examinations (half-yearly examinations conducted within the school) and not on assessment of skills such as verbal participation in class or class work.

3.16 The type of questions asked during these examinations varies across States. Questions could be objective or descriptive and the criteria used to evaluate student responses also differ across States. By and large the memory power of students is tested during these examinations. For example in Clarke's study of classroom practices (2001), teachers' notion of a good answer script in social studies is one in which all the facts are provided and for mathematics all the "steps" required to solve a problem are done correctly. Examinations often do not support the development of problem solving skills, application of knowledge and analysis of information.

3.17 Figure 6 portrays the success of students in the State Boards. The performance of students in HSE is only available for the government and aided schools and not for colleges. In the years 1993 to 1998, only 42 to 49 percent of the students for SE, and 47 to 59 percent for HSE were successful. This indicates the very low quality of education offered in government schools. Of the total number of students who appeared for State Board examinations, only 33 percent were girls. However, taking both SE and HSE together, girls obtain higher scores (2 to 36 percent) than boys across States. In SE, girls' performance is lower than boys in only three States -Assam, Bihar and Orissa - while in HSE, girls' perform better than boys across all States.

3.18 Apart from the State Boards, there are two other Boards that certify students in secondary and higher secondary education - the Council for Indian School Certificate Examinations (CISCE) and the Central Board of Secondary Education (CBSE). ${ }^{12}$ CISCE and CBSE are national Boards based in Delhi and operating in most of the States for both SE and HSE certification. Students who

\section{Figure 7: Student performance in examinations conducted by State and National Boards (1998)}

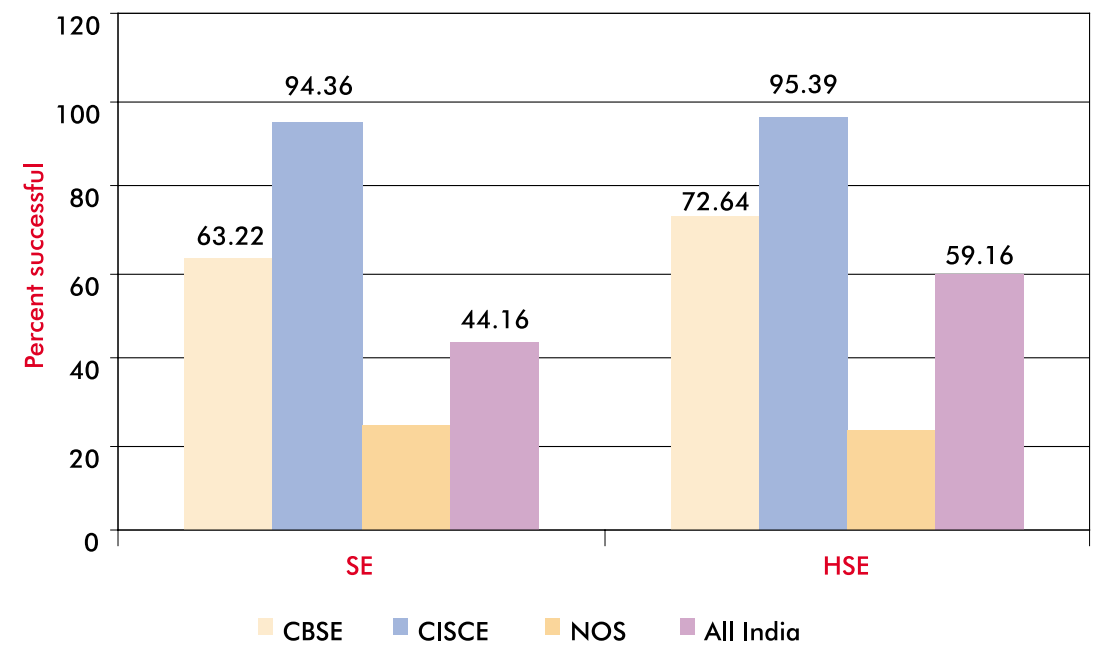

Source: Results of Secondary and Higher Secondary Examinations 1997 \& 1998, MHRD, Government of India, 2000

${ }^{12}$ The National Open School started in 1989, which also certifies students in secondary education will not be discussed in detail in this report. This program offers students who have dropped out of the system for various reasons a chance to complete secondary education through a self paced curriculum. Several States have started State Open schools. The enrollment in the NOS system is small compared to the established Boards of education. The Anglo Indian High School examinations for SE and HSE is also offered in a few States in India and is also not included in this study since the participation is very small. 
participate in these more competitive Boards are often from higher socio-economic backgrounds. In addition to laying down standards for schools, these Boards stipulate the curriculum and conduct examinations. The CISCE is a registered society functioning as a non-government organization. ${ }^{13}$ The medium of instruction is English and there are about 1100 schools in the country privately owned or run by religious trusts that offer these examinations. The CISCE curriculum has its own process of curriculum administration and development. The CBSE was established in 1929 and is a registered society responsible for 6000 schools across the country. This number includes 1400 schools run by the Delhi government, 800 Kendriya Vidyalaya Sangathan (KVS) schools, 480 Navodaya Vidyalaya Samiti (NVS) schools, and 3300 private schools across the country. CBSE has adopted the complete national curricular guidelines.

3.19 Figure 7 portrays the differences in achievement by the State and national Boards. On the average across States, 44 percent students in SE and 59 percent in HSE passed in the State Board examinations. In contrast, about 95 percent of the students appearing for SE and HSE through CISCE passed. In the CBSE conducted examinations, the pass rates for SE and HSE were 63 and 73 percent respectively. Pass rate through the National Open School (NOS) was the lowest at 23 percent.

3.20 Inequity is perhaps most evident in this certification process for SE and HSE. The proportions of SC and ST students (12 percent and 4 percent respectively of the total examinees) who appear for the examinations are low and the proportion of girls to boys within SC and ST communities appearing for certification are also low - for SC girls 24 percent and for ST girls 26 percent. Within SC, girls outperform the boys across States and within ST in some States girls perform better than boys. In CBSE, there are large differences between all students and SC students, reflecting the limitations of students from disadvantaged communities in a more competitive system.

\section{E. Vocational Education}

3.21 The first Commission which dealt with school education, the "Indian Education Commission" (188283), included a focus on secondary education, suggesting diversification of courses of instruction: "in the upper classes of schools there should be two divisions - one leading to the entrance examination of Universities, the other of a more practical character, intended for youth interested in commercial or other non-literary pursuits." This suggestion was unevenly implemented over the years. The 1964 Education Commission advocated that 20 percent of the enrollment in SE and 50 percent of HSE be vocational, and the 1986 policy advocated an overall 25 percent. More recently, the Central government with the intention of expanding this sub-sector, initiated the 1988 Centrally sponsored scheme to vocationalize education "to enhance individual employability, reduce the mismatch between the demand and supply of skilled manpower and to provide an alternative for those pursuing higher education without particular interest or purpose." Pre-vocational courses were introduced in 1993-94 "to impart training in simple marketable skills to the students of Grades 9 and 10, to develop vocational interests and to facilitate students in making a choice of vocational courses at the higher secondary level (MHRD Annual Report, 1995-96, p.47).”

3.22 Based on the most recent data available (1993), 4.8 percent of the share of enrollment is in vocational courses. The success of vocational education has been limited. The reasons for this include outdated equipment, unqualified instructors, irrelevance of curricula, and lack of textbooks and instructional material. In addition, the limited way in which vocational education is understood within a State's overall system of education for this level has also contributed to its limited achievement. While this was a Centrally sponsored scheme, according to Shariff and Ghosh (2000), the funding allocated within the overall education budget for vocational education by the Central government was small (3.2 percent) compared to the allocation for Kendriya Vidyalaya Sanghathan (46 percent) and

\footnotetext{
${ }^{13}$ The CISCE board replaced the Cambridge Local Examination Syndicate after Independence. It enjoys a distinctive status
} because of its previous connections with the Inter-State Board of Anglo-Indian Education. 
Navodaya Vidyalaya Samiti (34 percent). ${ }^{14}$ The $10^{\text {th }}$ Five-Year plan intends to expand this sector through cooperation with private enterprise and the CBSE national board.

3.23 Clearly, the conception of vocational education in its current form is narrow and involves training students for a particular occupation, which is often outdated, and less on the development of a set of generic skills that would allow students to adapt and relearn depending on the requirements of the labor market.

\section{F. Financing}

3.24 Financing has two aspects: public expenditure on secondary education and private costs to the individual student. With reference to the former (Figure 8), education is funded by State and Central government budgets through State and Central taxes and through fiscal transfers from Center to State (Bashir 2000). Taxation brings about issues of vertical and horizontal imbalances between the Center and the States and across States, which are to some extent assuaged through a system of Central transfers to the State. Three types of transfers between Center and State are identified. (i) Statutory transfers through adhoc grants from Central taxes; (ii) Block transfers supporting State plans for education; ${ }^{15}$ and (iii) Specific purpose grants also known as Centrally sponsored schemes (referred to earlier). State resources for education are mainly through tax and non-tax revenues in addition to what is received from the Center through the above methods of transfer. The content of what will be spent using both transfers and State funds are outlined in the State Five-Year-Plans. The Five-Year Plans outline what will be supported by the Center and the Annual plans define each year's Plans at the State level.

\section{Figure 8: Expenditure on Secondary Education}

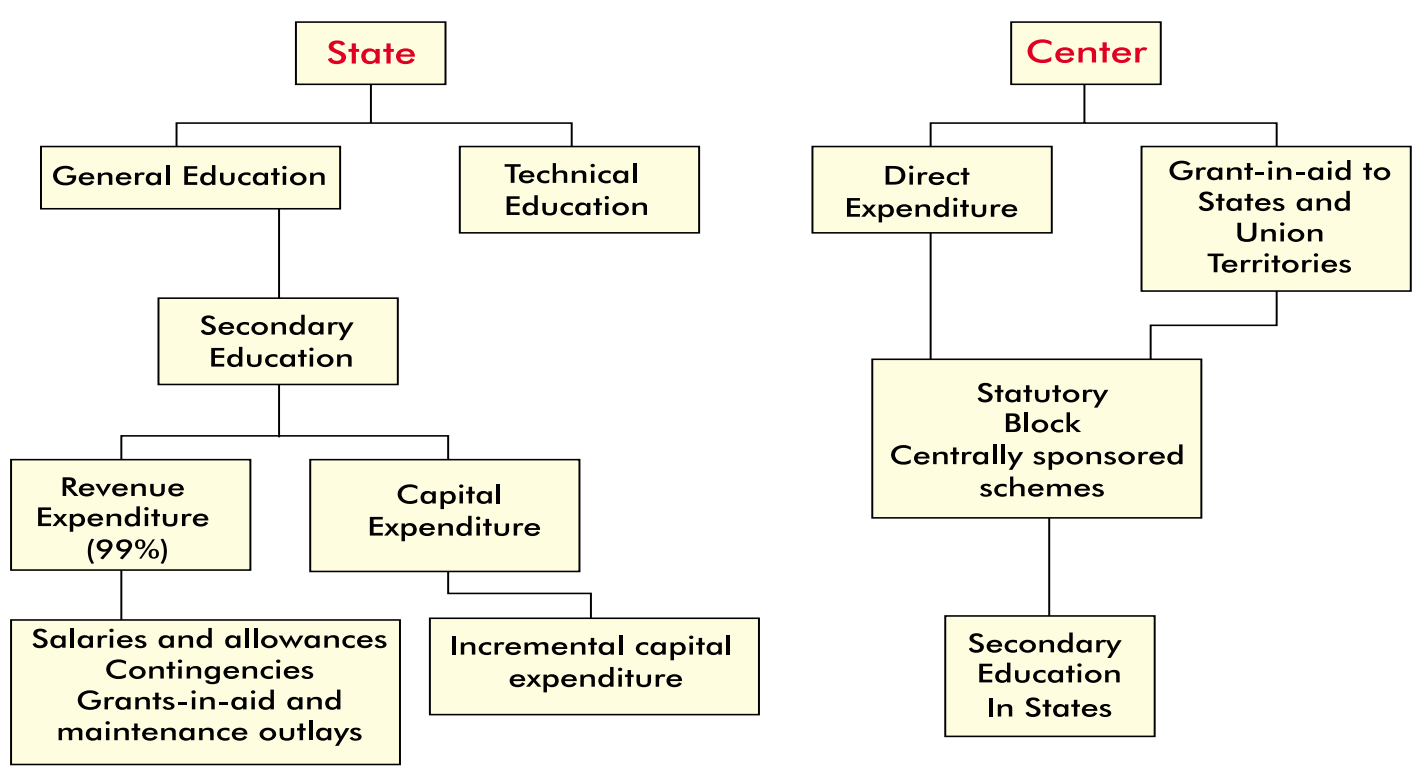

Source: Bashir 2000

\footnotetext{
${ }^{14}$ For a NVS school the allocation is Rs 105 lakhs; for a KVS school Rs 68 lakhs and for a vocational school Rs 65,000.

${ }^{15}$ The amount here is decided on the basis of population, economic status and negotiation between Finance, Planning Commission and State and Union governments.
} 
Table 5: Central Government financing of Secondary Education (Rs. Crore)

\begin{tabular}{|c|c|c|c|c|c|c|c|c|c|}
\hline & \multicolumn{3}{|c|}{ 1998-99 } & \multicolumn{3}{|c|}{$00-01$} & \multicolumn{3}{|c|}{$02-03^{*}$} \\
\hline & Plan & Non-Plan & Total & Plan & Non-Plan & Total & Plan & Non-Plan & Total \\
\hline $\begin{array}{l}\text { National Council of Educational } \\
\text { Research and Training }\end{array}$ & 6 & 28.3 & 34.3 & 10 & 25.7 & 36.6 & 12.6 & 35 & 47.6 \\
\hline Kendriya Vidyalayas & 87.1 & 435 & 522.1 & 95 & 490.6 & 585.6 & 76.5 & 544.8 & 621.3 \\
\hline Navodaya Vidyalayas & 291.5 & 85 & 376.5 & 349.4 & 88 & 437.4 & 324 & 122.6 & 446.6 \\
\hline Vocational Education & 6.6 & & 6.6 & 45 & & 45 & 45 & & 45 \\
\hline ICTs in Schools & 4 & & 4 & 5 & & 5 & 99 & & 99 \\
\hline Integrated Education for the Disablec & d 13 & & 13 & 15 & & 15 & 31.5 & & 31.5 \\
\hline Education Technology Programs & 15 & & 15 & 12 & & 12 & 0 & & 0 \\
\hline Promotion of science laboratories & 6.3 & & 6.3 & 20.9 & & 20.9 & 20.7 & & 20.7 \\
\hline National Open School & 3.5 & .15 & 3.7 & 5.7 & & 5.7 & 13.5 & & 13.5 \\
\hline Environment Orientation Program & 2 & & 2 & 3 & & 3 & 0 & & 0 \\
\hline Population Education Project & 2 & & 2 & 2 & & 2 & 2.0 & & 2.0 \\
\hline $\begin{array}{l}\text { Assistance for Boarding/ } \\
\text { Hostel facilities }\end{array}$ & 1.3 & & 1.3 & 2.5 & & 2.5 & 18 & & 18 \\
\hline $\begin{array}{l}\text { Central Tibetan Schools Society } \\
\text { Administration }\end{array}$ & 0 & & & 3 & & 3 & 2.7 & & 2.7 \\
\hline Other Programs & .61 & & & 5.7 & & 5.7 & 8.1 & & 8.1 \\
\hline Total & 4389 & 5484 & 9868 & 5742 & 6043 & 11794 & 6536 & 7024 & 13560 \\
\hline
\end{tabular}

Source: India Budget (different years); *provisional

3.25 Financing of secondary education has two components-Plan and non-Plan expenditure. Plan expenditure generally does not include regular and recurrent expenditure on education (which is called non-Plan expenditure). Plan expenditure at the Central level is what is transferred to States for special programs at the state level, while non-Plan would be for example for the running of KVS schools. ${ }^{16}$ Similarly, non-Plan expenditure at the State level

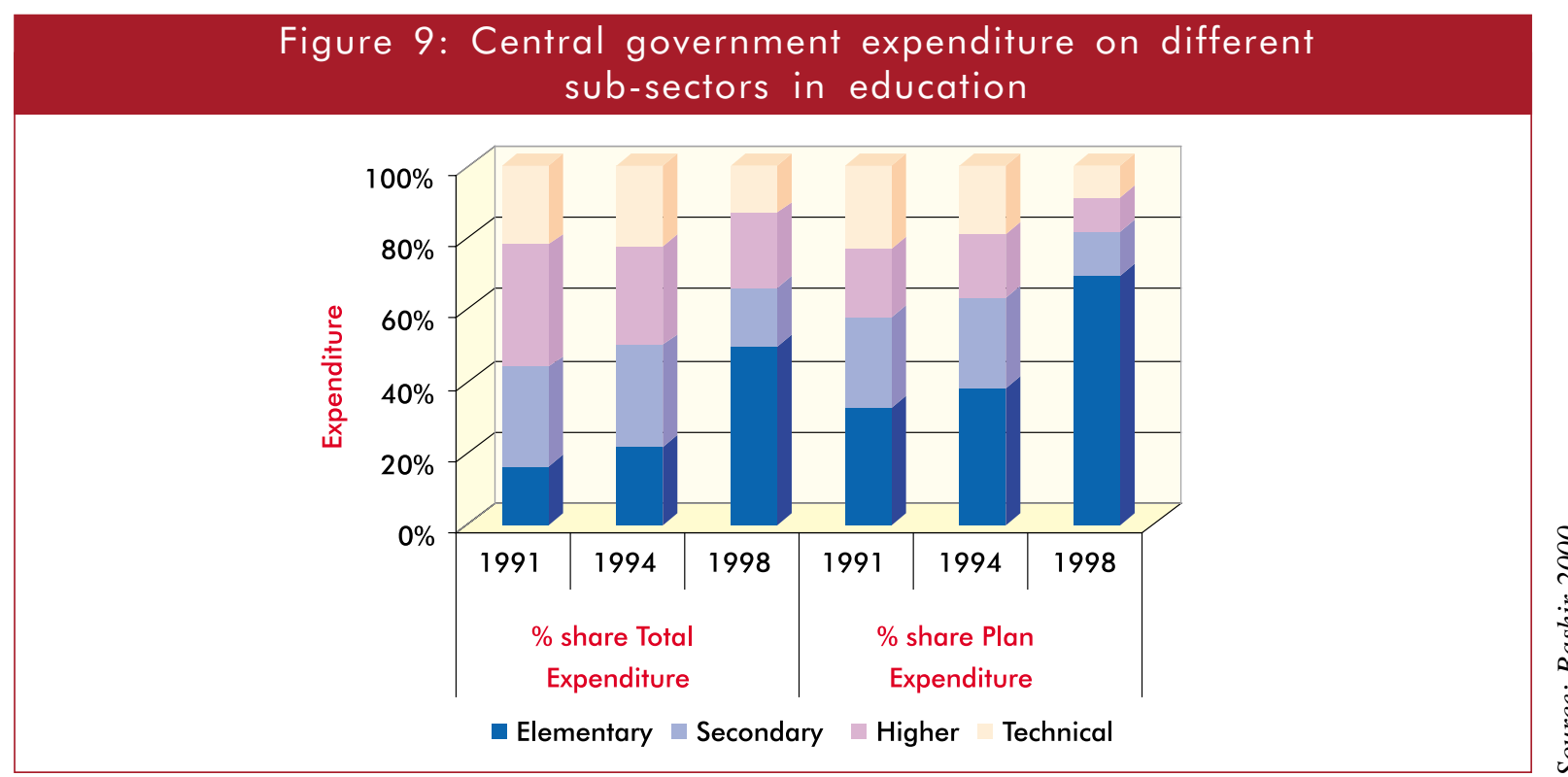

${ }^{16}$ Transfers to States from the Center could induce States to move their own Plan expenditure to other sectors thus reducing State expenditure on education. Plan expenditure for one year for items such as salaries etc could become "non-Plan expenditure" which is regular education expenditure in the following years. Civil work expenditure always remains Plan expenditure. 
Figure 10: Total expenditure on secondary education by Center and State

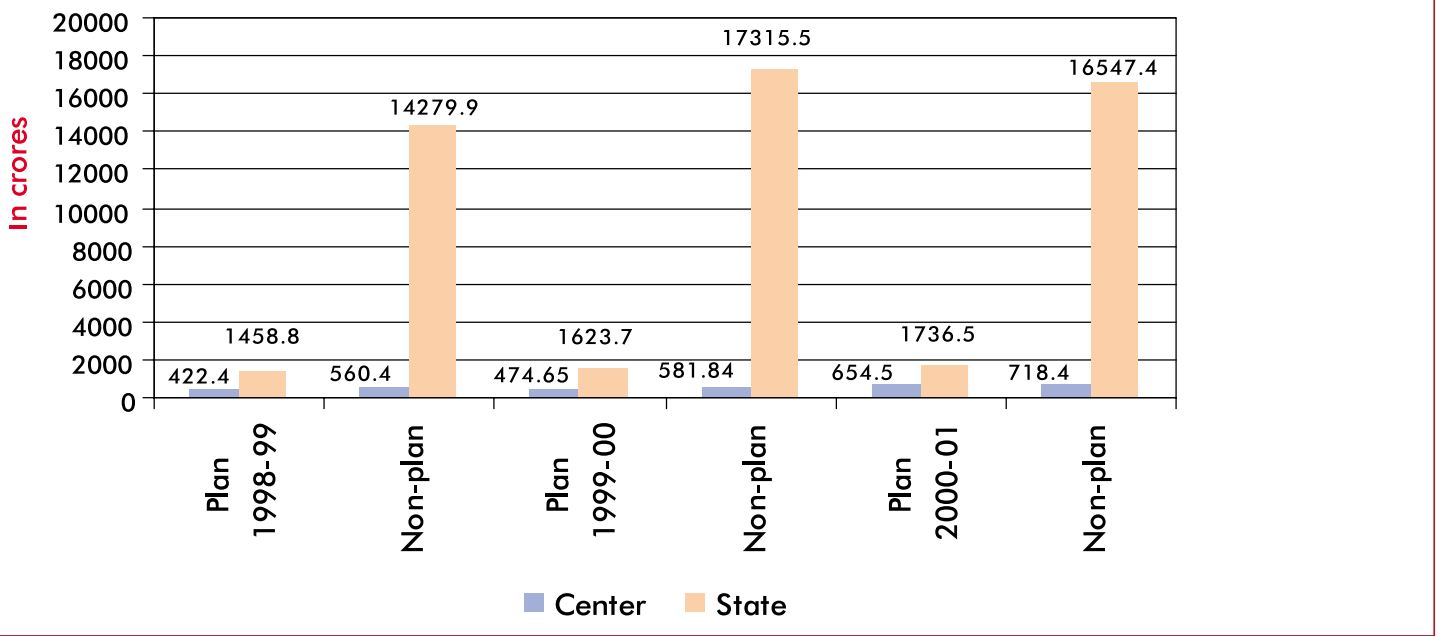

Source: India Budget different years

is for the regular functioning of the system while Plan expenditure is for special programs.

3.26 Table 5 lists the main programs funded by the Center. Kendriya Vidyalayas and Navodaya Vidyalayas, described earlier in paragraph 2.3, receive most of the funding. However, within the Central government expenditure, when secondary education is considered independent of elementary education (Figure 9), there is a sharp decrease in total Central government expenditure over the last decade from 24 percent in 1991 to 16 percent in 1998. Similarly, Plan expenditure declined from 19 percent to 8 percent. On the other hand, percentage expenditure on elementary education has increased to 33 and 40 percent of Total and Plan expenditure respectively. Compared to elementary education (36 percent), the growth rate in secondary education between the years 1991 to 1998 is 13 percent. This level of expenditure indicates the intention of the government to focus, thus far, more on elementary education rather than secondary education in order to meet the

\section{Figure 11: Percent expenditure of total education expenditure on secondary and higher secondary education across States (1999-2000)}

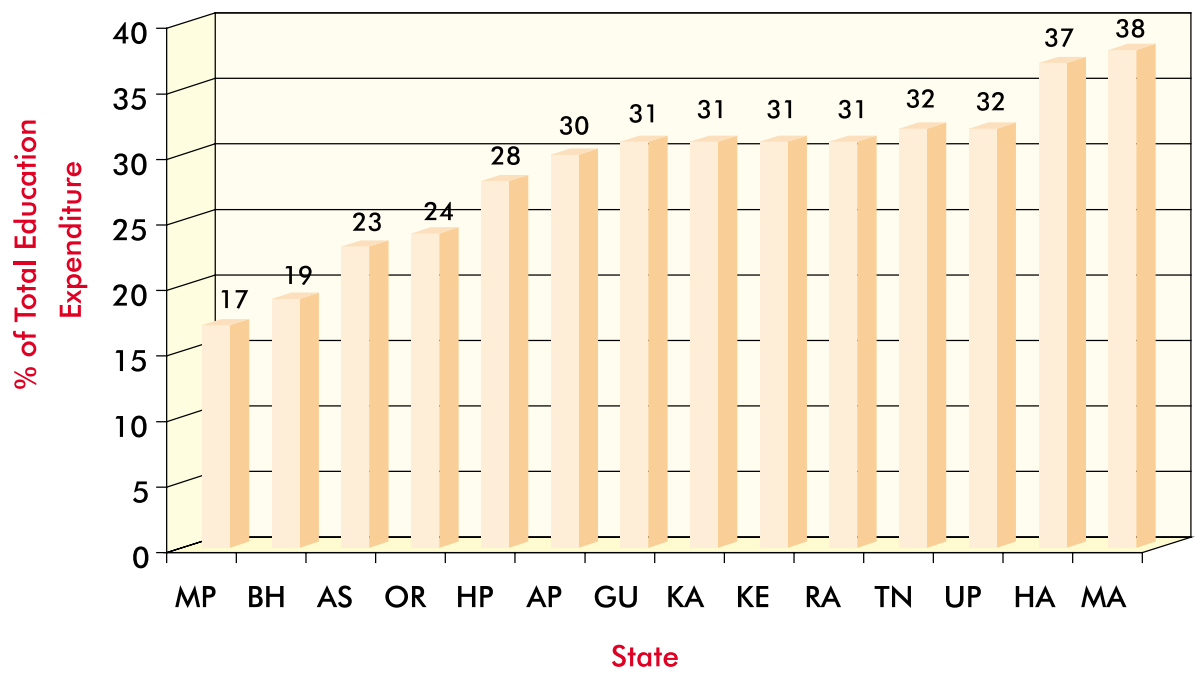

Source: Bashir 2000 


\begin{tabular}{|lcccccccc|}
\hline Table 6: Comparison of expenditure on secondary education & $\begin{array}{c}\text { of selected countries } \\
\text { Growth }\end{array}$ & $\begin{array}{c}\text { GNP } \\
\text { per } \\
\text { capita }\end{array}$ & $\begin{array}{c}\text { Average } \\
\text { annual } \\
\text { population } \\
\text { growth } \\
\text { rate }\end{array}$ & GER & $\begin{array}{c}\text { GNP } \\
\text { expenditure } \\
\text { on education }\end{array}$ & $\begin{array}{c}\text { Percent } \\
\text { on secon- } \\
\text { dary edu- } \\
\text { cation }\end{array}$ & $\begin{array}{c}\text { Per pupil } \\
\text { as penditure } \\
\text { of GNP per } \\
\text { capital }\end{array}$ \\
\hline Argentina & 4.2 & 8950 & 1.3 & 77 & 3.5 & 34.8 & 15 \\
\hline Brazil & 2.2 & 970 & 1.5 & 56 & 5.1 & 20.3 & 14 \\
\hline China & 10.0 & 860 & 1.1 & 70 & 2.3 & 32.2 & 12 \\
\hline India & 4.3 & 370 & 1.8 & 49 & 3.3 & 26.5 & 18 \\
\hline US & 1.7 & 29080 & 1.0 & 97 & 5.3 & 36.5 & 24 \\
\hline UK & 1.9 & 20870 & .2 & 129 & 5.4 & 44 & 20 \\
\hline
\end{tabular}

Source: World Education 2000

constitutional obligations of universal elementary education. The $10^{\text {th }}$ Five-Year Plan as discussed above could change this scenario, allowing SE and HSE to receive much more funding for improvements in this sub-sector.

3.27 While the Central government does provide some funds for secondary education, this amount is small compared to what the States spend on education (Figure 10). While Central funding is quite substantial in terms of Plan expenditure, the share of non-Plan expenditure is very small (about 3 percent).

3.28 There are two budget categories at the State level-General and Technical (Figure 8). The main source of funding for SE and HSE would be from the category of "General Education." Within the State's overall budget for education, the share of expenditure on SE and HSE ranges from 17 percent in MP to 38 percent in Maharashtra (Figure 11). If the State expenditure is examined, there are only a few schemes or little Plan expenditure on secondary education. Staff salaries constitute over 90 percent

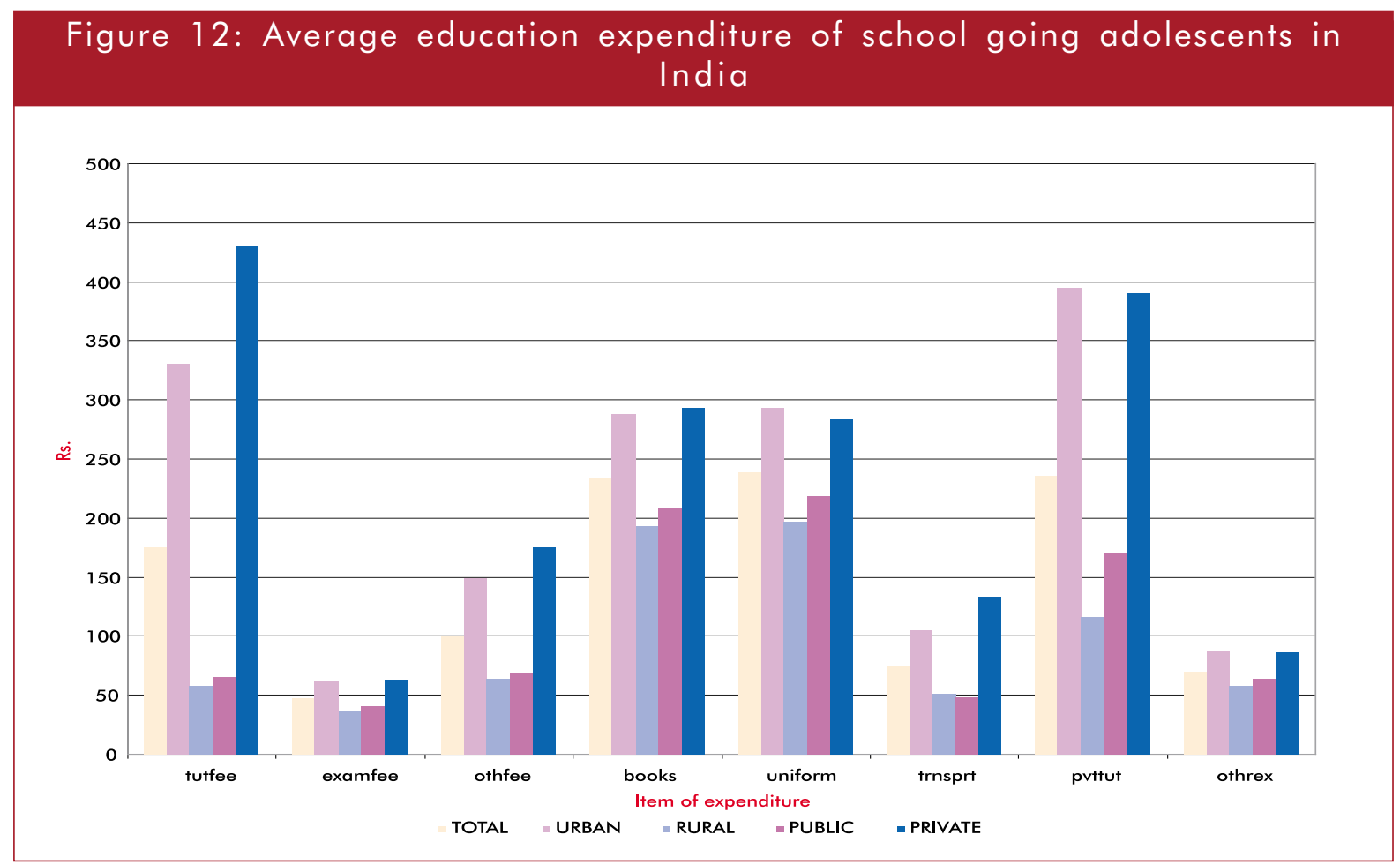

Source: NSSO $52^{\text {nd }}$ round $95-96$ (calculated) 
of the budget at the State level. Even when States do receive funds from the Central government for the Plan budget, due to financial deficits, the amount is used for expenditure, which would normally come under the non-Plan category. The funding for secondary education within the context of decentralization specified in the $73^{\text {rd }}$ and $74^{\text {th }}$ Constitutional Amendments will have implications for funding in secondary education. At the present States release untied funds to panchayats or local governments, which can be used for secondary education.

3.29 The expenditure on secondary education in India can be compared to expenditure on secondary education in other countries (Table 6). Except for China, expenditure on education in India as a percentage of Gross National Product (GNP) is low. In addition, the proportionate expenditure on secondary education is also low, though per pupil expenditure as percent of GNP per capita is higher than Argentina, Brazil and China. This suggests that unless spending on secondary education increases and more importantly, per pupil expenditure becomes more targeted and efficient, it will not be possible to improve this sub-sector.

3.30 When private costs for the secondary school student in India is considered, the highest costs are incurred on books, private tuitions, uniforms and school tuition fees. Data is not available comparing urban public and private schools or rural urban and private schools, though information is available comparing costs for rural and urban, and private and public school students (Figure 12). The data suggests that public school students incur a fair share of household expenses for their education. The cost of private tuition and school tuition fees clearly distinguishes urban and rural schools as well as private and public schools. An interesting question to ask here is that if no private tuitions were available would private school students' performance be similar to that of public school students? The extent to which a student can afford private tuition as a determinant of success relative to school quality is an area that needs to be examined.

\section{ISSUES IN SECONDARY EDUCATION}

4.1 Both secondary and higher secondary education in India has developed over the years through some amount of planning at the national level but for the most part, until recently, naturally and inevitably in the States. In examining issues in this sub-sector, the need for deliberate planning for this level of education at the State level and its integration into the broader strategy for education in the States is highlighted. This section includes a discussion of the positioning of secondary education, improving quality in SE and HSE, and the financing of SE and HSE nationally and in the States.

\section{A. The Positioning of Secondary Education}

4.2 Three areas are discussed that deal with the positioning of secondary education in the country. First is the issue of whether this sector should expand and how large it ought to be. Only an average of 35 percent of the eligible school age population in the country attends secondary school. Based on the pattern of increase in enrollment over the last 50 years, the increased demand for primary education and the fact that secondary schools now only cater to a quarter of the primary school students, an increase in the demand and size of the secondary school sub-sector seems inevitable. The recent analysis (World Bank, 2002b) of the rates of returns to education in India suggests the positive effects of expanding this sector. Working secondary school graduates earned salaries 2.9 times higher than that of illiterate workers and 1.7 times that of workers with primary school education. The benefits were higher for female workers with secondary education. ${ }^{17}$ The private rate of return for females with secondary education was 50 percent and for males 14

\footnotetext{
${ }^{17}$ Bashir in this World Bank report also found that the differential gap between the workers with different educational backgrounds increased with age..
} 


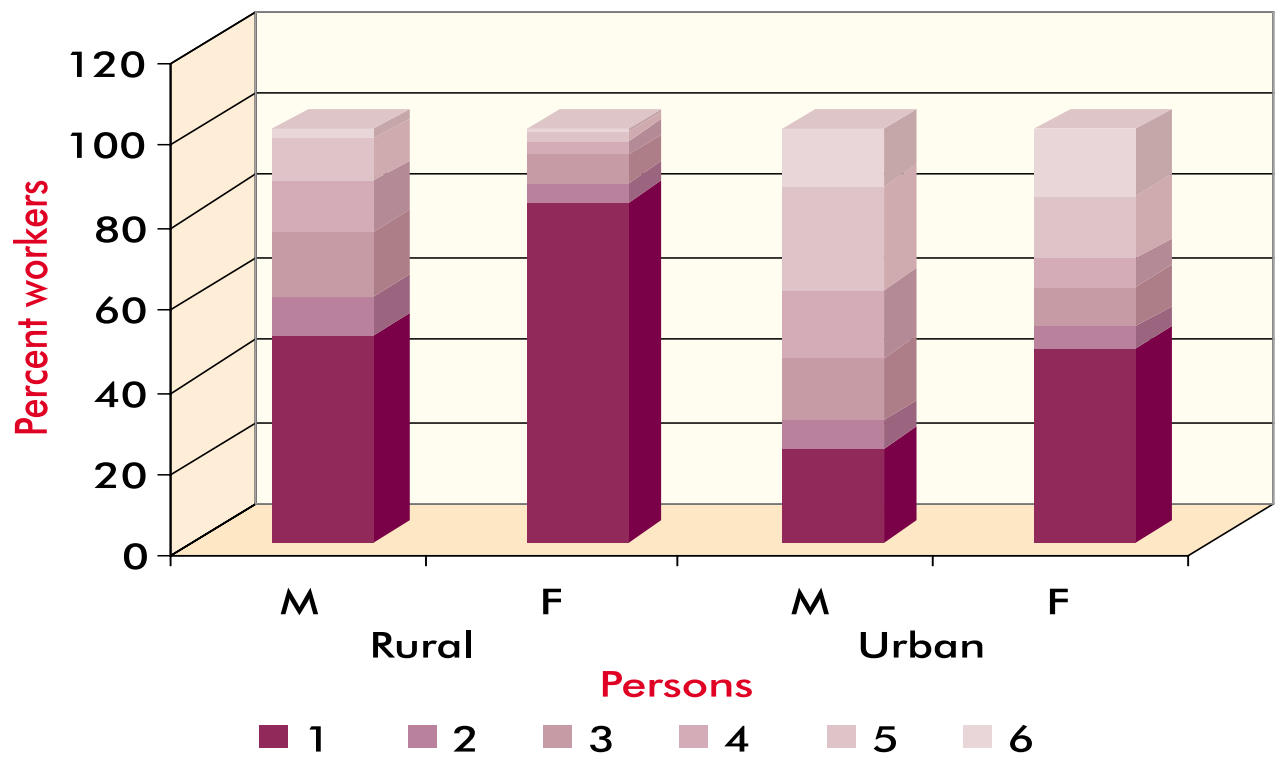

Source: Census 1991. 1: Illiterate 2: Without primary 3: Primary 4: Upper Primary

5: Secondary 6: Higher Secondary.

percent; the public rate of return was 13 and 40 percent respectively. A recent study by Godo (2002) comparing economic growth and its relationship to education in the US, Japan and Korea demonstrates the growth in secondary and vocational education playing a critical role in each country's rapid development. ${ }^{18}$ The impact of secondary education on economic development is not the only criteria for developing this sub-sector, and while it has not yet been quantified, the impact of secondary education on empowering individuals to take control of their situation cannot be underestimated.

4.3 The question then, is how should governments respond to this demand and define the size of the sector? Since States are mainly responsible for providing secondary education and for ensuring the quality of education, it will be important for State departments of education to make deliberate decisions on how large this sector should be based on the requirements for an educated labor force, the relative needs and capacity of higher education and on the question of which communities should be given more encouragement based on issues of equity. Estimating the requirements of the labor force suggests the need for close collaboration of this sub-sector with the departments that deal with labor and industry. Figure 13 indicates that 20 and 40 percent of the rural and urban SE and HSE school male graduates respectively are in the workforce. The number is much less for females. More students proceed to higher education in the urban areas than from the rural areas. Most of the southern States and few of the northern States have expressed their concern regarding an adequately trained labor force and are beginning to address this issue. Karnataka has gone a step further in doing a detailed and comprehensive situational analysis of SE and HSE and is discussing ways to reform SE and HSE to be more in line with the requirements of the labor market. With reference to equity, considering the low enrollment of female, SC and ST students, the growth of student enrollment from these groups is an area that requires specific attention.

${ }_{18}$ The paper by Yoshihasa Godo from Meiji Gajuin University in Japan was presented at the Bank in May 2002. Godo makes the point that Japan and Korea have had to give considerable attention to education in order to reach levels similar to the US, allowing these countries to have sufficient human capital to influence economic "catch up" with the US. Korea was slower than Japan. Elementary and secondary education was critical in this process and not so much higher education. 
4.4 Secondly, there is the issue of the institutional location and responsibility for secondary education in the States. Two aspects define this issue. The first is the extent to which private, aided and government institutions will cater to secondary and higher secondary enrollment. Clearly, private institutions may not be able to accommodate students from the poorest quintiles. On the one hand, the decline in aided school enrollment over the last decade indicates the State governments' declining support for publicly subsidized private education. On the other hand, the increase in government school enrollment demonstrates that students from the poorer quintiles, unable to afford private secondary schools, are joining the government system with its low quality. This situation suggests that governments must decide whether to enlarge the aided or publicly subsidized private education or concentrate its efforts on increasing access and on improving the quality of government secondary schools, which will indeed be expensive. Perhaps, in addition to improving the quality of government secondary schools, support could be given to aided schools, which could reduce the burden on government schools. It will be important while rethinking support to aided schools, to ensure that a regulatory framework and an accountability system are in place to ensure adequate student performance in these schools. The possibility of involving the private sector through vouchers is an intervention that is being explored in several countries. The voucher scheme involves the provision of funding to the individual student to choose a private provider. ${ }^{19}$ This scheme while supporting school autonomy, could precipitate private schools to work on improving quality and thus draw students into the system.

4.5 The sharing of higher secondary with the university system in some States is another aspect, which has administrative and financial implications. The question of whether this dual administration will continue in these States needs to be addressed. While at the national level, there is support for transferring all HSE education to schools, understandably the politicization of this issue makes it difficult for some States to implement this transfer. However, in order to regulate and monitor this sector as a whole, and if universities are going to continue to be providers of HSE, their role and reach in the student population will have to be incorporated into the total plan for SE and HSE in the State. If the State is able to implement the policy of closing down the university provision of secondary education, then the focus of reform could be confined to HSE in schools. The point made here is that if higher education is going to be involved, it will be important to ensure integrated planning and management with school education with regard to HSE. If this does not take place there will be confusion and duplication of services provided within the State, which would later be difficult to rationalize.

4.6 Thirdly, the content of secondary education must be considered in positioning secondary education in the State and in the country. While this is an issue of national and State sovereignty, there is undoubtedly an impact of the content of education at this level on the economic development of the States and the country as a whole. ${ }^{20}$ The success achieved in providing personnel for the Information Technology industry is a case in point. The strong emphasis on mathematics in secondary education (mostly in the private and aided school sector) and the expansion of the private provision of posthigher secondary information technology (IT) training at the right time, helped this industry develop nationally and internationally. Similarly, the contribution of secondary and higher secondary in the future will depend upon how States respond to the local, national and international requirements in

\footnotetext{
${ }^{19}$ Gauri and Vawda (2003) discuss the relative benefits of the voucher scheme based on a literature review. In both industrialized and developing countries they found that vouchers were useful when they are targeted for the poor and operate in an urban setting especially when there is collaboration with existing private schools.

${ }^{20}$ The national debate on the NCERT curriculum, especially the social studies curriculum, over the last two years is interesting. This debate focuses on whether the right and left wing perspectives of history are acceptable. The emphasis, however, in this paper is the choice of subject and the organization and relative importance given to science and mathematics in the curriculum.
} 
structuring the content of this level of education for government school students both in terms of overall goals, subjects offered and the way in which subjects are taught and how students learn.

4.7 At the national level, there appears to be a dual emphasis - IT and vocational education. The GOI Annual Report on Education (2000-01) outlines the collaboration between MHRD with the Department of Electronics to introduce on a pilot basis the scheme of Computer Literacy and Studies in Schools. The reach and impact of this scheme are not known. According to Saxena et al's study (2000) of computers in secondary education in Rajasthan, the situation is rather dismal in government schools. Two points could be highlighted here. One is the direction of IT education evident in schools. In its current form within a traditional curriculum, schools tend to instruct students in the use of the computer and in computer languages. Computers are rarely used to optimally enhance student learning within subject areas, which is possible only if the curriculum is indeed revised to focus less on accumulating information but more on analyzing and applying it. The other issue is the widening gap between private and government schools with respect to IT education. In order not to allow the differences between government and private schools to become more pronounced, it will be important for substantial investments to be made on computer education in government schools. In addition to increasing government spending, partnerships with the private sector, which are taking place in some States (Karnataka and Madhya Pradesh), is perhaps the way of the future for developing IT skills of SE and HSE students. ${ }^{21}$

4.8 GOI may wish to re-examine its focus on vocational education in the light of international experience. On the one hand, according to Bennell and Segerstrom (1998), an evaluation of vocational education programs in several Latin American countries showed that academic or general education had better outcomes than vocational training. In fact there is no clear evidence, at least in the Latin American countries under review, that academic secondary school leavers (who do not go to universities) are worse-off in the labor market than the vocational school graduates (Castro et al, 2000). On the other hand, in the OECD countries, vocational education constitutes a sizable segment of the secondary school sector. Several of the rapidly growing economies of South East Asia also put emphasis on vocational education at an early stage in their industrialization processes. During the 80 s, a sizable proportion of senior high school students were studying vocational subjects in these countries. China too adopted, from the very start of industrialization, a very proactive and aggressive manpower development strategy and great efforts were made to vocationalize its secondary education since the late 70s (Yang, 1998). The success of these programs were due to the speed with which vocational education responded to the changing environment, in addition to effectively developing students' basic skills of mathematics, language and science.

4.9 In most of these countries where vocational education is working well (Bagnall 2000; Megahed, 2002), it is not structured the way it is in India. Vocational education courses in other countries offer definite possibilities for apprenticeships after graduation, which is not the case in India. Employers after graduation may or may not offer apprenticeships to students and, as seen in some States, students are unable to obtain apprenticeships. For instance, in the case of Assam, out of 2000 students who went through vocational training only 157 were able to become apprentices. In most countries that offer vocational training, the employers and industries are directly involved as in the German model, which allows students to work for a few days each week and study during the rest of the week. This establishes connections with the work place for the students and also gives them experience on the job. In some cases, industries subsidize the cost for such programs.

\footnotetext{
${ }^{21}$ Interesting partnerships with the private sector are now in place to provide computer education. For example in Karnataka, a few companies provide the machines to schools for use during the day and the companies use it for profit after school and during weekends.
} 
At the same time the core courses are taught to these students and the levels are sufficiently high to allow them to proceed for higher studies if they so wish. Several countries are now opting for this model, which then prevents the school system from investing in vocational education without confirmed jobs for students. In addition, vocational education students are not barred from competing for places in higher education.

4.10 While IT and vocational areas are critical, especially within the Indian context with its high rate of poverty, the development of lifelong learning skills that support a knowledge economy is also critical. $^{22}$ The knowledge economy refers to an economy that is based on the development of ideas and the application of technology. Lifelong learning is the acquisition of a new set of skills "such as learning-to-learn, and analytic and group skills to be able to update skills successfully throughout their lives (World Bank, 2003)." The importance of lifelong learning skills and of paying attention to content are reiterated by a recent World Bank study (2002b) in India, which examines the perceptions of employers of SE and HSE graduates. According to the employers, secondary education graduates lacked knowledge and skills especially in communication; they were also not open to learning new skills. This study suggests that rather than prepare students for a particular skill, secondary education could prepare students with a set of generic skills that will help them adapt and learn quickly. These findings have implications for both vocational education to develop more generic skills and for general education to rethink its preparation of students.

4.11 There is limited information on the emphasis or direction of curricula at the State level. Based on the limited information available, the curricular objectives at the State level appear not to have significantly deviated from the direction and emphasis given by the Center. There is no systematic evaluation of curricula at the State level. Revisions are made on an ad hoc basis, sometimes on the basis of popular request or on the basis of national compulsion. It will be critical for State systems of secondary education to take on this task of putting in place a process that allows continuous reviewing and re-definition of curricular content. States could take their cues from the national level Boards of Examination. The national level Boards appear to be pace setters in revising the content of secondary and higher secondary curricula in response to national and international developments. For example, the CISCE's introduction of computer and environment studies at the secondary level has been highlighted by MHRD (1997) as a significant intervention. State Boards of Education would do well to emulate some of these practices.

4.12 Having said this, however, it is noted that the national Boards have not significantly altered their curricula and examinations to focus less on rote learning and memorization and more on the lifelong skills discussed above. Thus redefining the objectives of SE and HSE could be the task of both the national and State Boards of Education. Since the State Boards are the main providers of government SE and HSE, it would be useful for States as well as national Boards to define the direction for their SE and HSE curricula, and to emphasize lifelong learning within the overall curriculum. In examining and revising curricula, the inputs from Higher Education in addition to other Departments such as the Departments of Labor and Industry would be helpful.

\section{B. Improving the Quality of Secondary Education}

4.13 Student achievement rates discussed earlier indicate the low quality of secondary and higher secondary education in State government school systems across the country. Since most of

\footnotetext{
${ }^{22}$ Saxena et al (2000) evaluates the use of computers in the secondary education system in Uttar Pradesh (U.P). The survey involved student alumni, teachers and representatives of the managements of various schools. The survey indicated that government schools and other Hindi-medium schools did not have computer studies in their curriculum. It was found that almost all private schools had computer studies in their regular curriculum.
} 
Table 7: Availability of Toilets

\begin{tabular}{|lccccc|}
\hline $\begin{array}{l}\text { Location and } \\
\text { Management }\end{array}$ & Toilet & $\begin{array}{c}\text { Percent SE with } \\
\text { Toilet for } \\
\text { girls only }\end{array}$ & & Percent HSE with \\
\hline Rural & & & & $\begin{array}{c}\text { Toilet for } \\
\text { girls only }\end{array}$ \\
\hline Government & 45.77 & 26.86 & 64.04 & 41.73 \\
\hline Private aided & 53.16 & 37.67 & 76.32 & 61.77 \\
\hline Private unaided & 34.83 & 27.44 & 63.28 & 54.53 \\
\hline Urban & & & & 87.18 & 63.57 \\
\hline Government & 74.62 & 52.02 & 95.68 & 76.34 \\
\hline Private aided & 89.47 & 72.41 & 94.94 & 88.33 \\
\hline Private unaided & 91.12 & 81.11 & & \\
\hline
\end{tabular}

Source: Sixth All-India Education Survey (1993)

the CISCE schools and a large proportion of the CBSE schools are private, the State Boards and the government schools are mainly implicated. Clearly, improving the quality of education provided is critical both in terms of supplying an adequately trained work force, empowerment of the individual student and in terms of equity. The discussion of improving quality will be limited to the government and aided schools except where issues of regulating the private sector are concerned. In addition, HSE attached to the university system will not be dealt with mainly due to lack of data and due to its affiliations with higher education. Improving quality can be discussed at three organizational levels - at the school level, at the classroom level, and at the administrative level. Before dealing with ways to improve quality within the three levels, certain basic prerequisites or minimum physical infrastructure necessary for any reform in secondary education are discussed.

\section{B.1 Physical Infrastructure Needs}

4.14 This paper does not deal with infrastructure needs based on future expansion of the sector but confines the discussion to the current needs in this area. Even in the present system, without information on individual school enrollment and movement of students from the government school system to the aided or private schools or from aided to government schools, it is difficult to estimate additional infrastructure needs in this sector. Having said this though, the need in rural areas appears to be greater than that in the urban areas, which is understandable taking into consideration the availability of private schools in urban areas.

4.15 The physical condition of schools does influence the quality of education provided. This paper maintains that adequate classroom space and laboratories are necessary minimum conditions to enable learning to take place. The present condition of physical infrastructure shows that only about 65 percent of the rural schools and about 75 percent of the urban schools are operating in what are called "pucca" or permanent buildings. About 25 percent rural and 20 percent urban schools are in partially pucca buildings (inadequate buildings) or in some cases even in open spaces. Partially pucca buildings are fewer in HSE. These figures indicate the need for improving the physical structure of schools, especially in Assam, Bihar, Himachal Pradesh, Orissa and Tamil $\mathrm{Nadu}$, where only about a third of the buildings are partially pucca for secondary education. While drinking water is available in the majority of schools, there are a large number of secondary and higher secondary schools, which do not have separate toilets for girls, an essential item for encouraging girls to come and stay in school. As Table 7 illustrates, the number of schools, which have separate 
Table 8: Availability of Science Laboratories and Librarians

\begin{tabular}{|c|c|c|c|c|c|c|}
\hline \multirow[t]{2}{*}{ Management } & \multicolumn{2}{|c|}{ Percent in SE schools with } & \multicolumn{4}{|c|}{ Percent in HSE schools } \\
\hline & Labs & $\begin{array}{l}\text { Fulltime } \\
\text { Librarian }\end{array}$ & $\begin{array}{c}\text { Subject } \\
\text { Labs }\end{array}$ & $\begin{array}{c}\text { Combined } \\
\text { Lab }\end{array}$ & $\begin{array}{l}\text { No } \\
\text { labs }\end{array}$ & $\begin{array}{l}\text { Fulltime } \\
\text { Librarian }\end{array}$ \\
\hline \multicolumn{7}{|l|}{ Rural } \\
\hline Government & 49.29 & 11.23 & 45.67 & 28.85 & 10.03 & 26.42 \\
\hline Pvt. Aided & 61.55 & 3.94 & 68.83 & 11.71 & 8.34 & 36.58 \\
\hline Pvt. Unaided & 52.82 & 7.36 & 56.96 & 23.10 & 6.52 & 39.74 \\
\hline Total & 54.05 & 8.35 & 54.11 & 22.88 & 9.13 & 32.14 \\
\hline \multicolumn{7}{|l|}{ Urban } \\
\hline Government & 63.52 & 15.57 & 67.99 & 13.70 & 6.36 & 47.88 \\
\hline Pvt. Aided & 74.35 & 11.57 & 75.31 & 5.93 & 6.46 & 52.56 \\
\hline Pvt. Unaided & 76.93 & 23.03 & 70.96 & 12.10 & 5.34 & 54.23 \\
\hline Total & 71.21 & 16.43 & 71.35 & 10.44 & 6.20 & 51.03 \\
\hline
\end{tabular}

Source: Sixth All India Education Survey (1993)

toilets for girls is only a third in rural areas and differences are quite apparent in this regard between government and private schools in the urban area.

4.16 Availability of laboratories (Table 8) in schools is limited especially in rural areas. Of all the schools in India offering science stream, only 60 percent of SE schools and 80 percent of HSE schools

\section{Table 9: State-wise availability of Laboratories and Librarian}

\begin{tabular}{|c|c|c|c|c|c|c|}
\hline & \multicolumn{2}{|c|}{ Percent SE with } & \multicolumn{4}{|c|}{ Percent HSE with } \\
\hline & $\begin{array}{l}\text { Full time } \\
\text { librarian }\end{array}$ & $\begin{array}{c}\text { Science } \\
\text { laboratory }\end{array}$ & $\begin{array}{c}\text { Subject } \\
\text { laboratory }\end{array}$ & $\begin{array}{l}\text { Combined } \\
\text { laboratory }\end{array}$ & $\begin{array}{c}\text { No } \\
\text { laboratory }\end{array}$ & $\begin{array}{l}\text { Full time } \\
\text { librarian }\end{array}$ \\
\hline Andhra Pradesh & 12.28 & 44.99 & 72.36 & 7.27 & 10.58 & 49.53 \\
\hline Assam & 2.64 & 6.18 & 68.42 & 13.53 & 11.28 & 7.87 \\
\hline Bihar & 4.43 & 67.15 & 57.78 & 12.70 & 24.76 & 44.20 \\
\hline Gujarat & 1.70 & 85.96 & 88.62 & 3.55 & 5.92 & 61.36 \\
\hline Haryana & 3.77 & 83.40 & 70.83 & 9.17 & 2.92 & 26.67 \\
\hline Him. Pradesh & 4.09 & 77.71 & 68.05 & 8.28 & 1.18 & 51.45 \\
\hline$J \& K$ & 23.15 & 76.92 & 70.12 & 19.91 & 2.60 & 82.91 \\
\hline Karnataka & 9.94 & 48.09 & 52.44 & 25.19 & 13.88 & 25.86 \\
\hline Kerala & 5.26 & 80.99 & 62.14 & 22.33 & 5.83 & 17.96 \\
\hline Madhya Pradesh & 7.45 & 56.97 & 44.11 & 41.68 & 3.85 & 19.05 \\
\hline Maharashtra & 5.57 & 83.49 & 78.77 & 0.00 & 19.35 & 25.92 \\
\hline Orissa & 7.85 & 15.08 & 58.43 & 6.74 & 31.46 & 64.23 \\
\hline Punjab & 8.31 & 70.63 & 64.92 & 12.79 & 9.51 & 41.80 \\
\hline Rajasthan & 70.30 & 82.93 & 78.43 & 3.79 & 3.14 & 86.37 \\
\hline Tamilnadu & 3.60 & 47.35 & 48.48 & 16.80 & 4.87 & 20.71 \\
\hline Uttar Pradesh & 11.01 & 60.35 & 68.17 & 6.04 & 10.00 & 44.44 \\
\hline West Bengal & 3.94 & 41.60 & 83.70 & 5.62 & 4.48 & 55.33 \\
\hline All India & 10.53 & 59.72 & 64.37 & 15.47 & 7.38 & 41.77 \\
\hline
\end{tabular}

Source: Sixth All-India Education Survey (1993) 
have laboratories. The situation (Table 9) is worse in Assam and Orissa where only 15 and six percent respectively of the secondary schools had a laboratory. About one percent (Himachal Pradesh) to 31 percent (Orissa) schools in HSE did not have a laboratory. Libraries are important, though not as much within the existing instructional scenario with its emphasis on textbook learning. Within a system that is focused on developing more complex skills of reasoning and analysis, libraries would be crucial. Data on whether schools possess libraries is unavailable; however, information on whether there is a librarian is available. It is not clear how useful this knowledge is without information on whether there are books in the library! For what it is worth, full time librarians are more in higher secondary schools.

4.17 Class sizes and relatedly teacher-pupil ratios influence levels of learning especially for students who are below average. Average teacher-pupil ratios (TPR) suggest that class sizes appear to be appropriate (1: 30 in SE and 1:34 in HSE) in most States. However, the average TPR hides the wide variation in class sizes across, within States and between schools, which are alluded to in different studies and for which actual data are not available. Some classrooms have less than ten students while others in the same school may have over seventy students. This point also relates to an optimum school size for SE and HSE schools. The student population in many schools, especially in urban areas (due to the expansion of the private sector) is sometimes too small for the institution to be viable and effective. The number of female teachers in classrooms to encourage girls' participation is low and ranges from 13 percent in Bihar to 59 percent in Kerala.

\section{B.2 At School Level}

4.18 School level improvement is an important aspect of SE and HSE reform. Mukhopadhyay and Kumar (2001) in their study of 12 aided and seven government schools in Rajasthan found that school climate or ethos characterized by a principal with a vision and ability to motivate teachers and parents made certain schools more effective than others. It is unlikely that there is much autonomy and school level planning in government schools. Duraiswamy and Subramaniam's (1999) study of the effect of school management found that about 61 to 89 percent of the differences between the achievement of students in public and private (aided and unaided) schools were accounted for by management practices adopted by schools. Management practices in private schools include autonomy in student admissions, teacher recruitment, and expenditure. In addition to autonomy, other significant areas critical to school functioning include effective time management especially of teachers, school organization and accountability frameworks.

4.19 Due to the culture of top down management, it is unlikely that school level planning exists in government schools. It will be important to assist each school in conceptualizing its own strategic plan for development. Based on a situational analysis of the school, plans could outline annual and long-term goals and ways to achieve these goals. Areas that seem to be detrimental to effectiveness could be identified and addressed in school development plans. School plans could include improvement of physical facilities, teaching and learning in classrooms, and professional development. In order to develop capacity for this kind of school level planning and management, it will be critical to target headmasters or school principals. In order for school plans to become effective, it would need to be supported by District and State Education Departments with financial and technical assistance.

4.20 Most countries at this stage of education have in place guidance or counseling service for students to assist them in understanding the choices either in higher education, in technical training or in the labor market. A system of student counseling does not exist in India. Family members and sometimes teachers help students make decisions about their future. It is critical to set in place a system that 
Table 10: Characteristics of traditional and lifelong learning models

\begin{tabular}{|l|l|}
\hline Traditional learning & Lifelong learning \\
\hline - The teacher is the source of knowledge. & $\bullet$ Teachers are guides to sources of knowledge \\
\hline Students receive knowledge from the teacher. & $\begin{array}{l}\text { Students learn from the teacher, from other sources } \\
\text { of knowledge and from lived experience }\end{array}$ \\
\hline $\begin{array}{l}\text { - Testudents work gy themselves. } \\
\text { completely mastered a set of skills and to ration access to } \\
\text { further learning. }\end{array}$ & $\begin{array}{l}\text { - Students learn in groups and from each other } \\
\text { identify pathways for future learning }\end{array}$ \\
\hline - All students do the same thing. & $\bullet$ Teachers develop individualized learning plans \\
\hline - Teachers receive initial training plus ad-hoc inservice training. & $\begin{array}{l}\text { Teachers are lifelong learners. Initial training and } \\
\text { ongoing professional development are linked }\end{array}$ \\
\hline $\begin{array}{l}\text { "Good" students are identified and permitted to continue } \\
\text { their education. }\end{array}$ & $\begin{array}{l}\text { - Students have access to learning opportunities over a } \\
\text { lifetime }\end{array}$ \\
\hline
\end{tabular}

Adapted from World Bank 2003.

would enable students to receive advice from professionals aware of the different options especially at the end of SE and HSE. This kind of a system would be very helpful to students if it can be implemented in India.

\section{B.3 At the Classroom Level}

4.21 The performance of students in examinations within the government school system suggests that teaching and learning in classrooms is weak across States. In the model that is currently practiced in classrooms, instruction upholds rote learning and memorization (Clarke 1997; 2001). Class sessions consist of teachers lecturing from the textbook and asking closed questions requiring answers from the textbook. There are two approaches to improving the quality of education at this level. The first approach assumes that the content of SE and HSE and the way in which teachers teach in classrooms at present are acceptable, then the question to be dealt with in this discussion would be as to how student performance in examinations can be improved. The low participation rate of students in rural areas in the science stream is a significant concern and as mentioned earlier, indicates students' lack of confidence in learning science (possibly due to weak upper primary education) and weak instruction in classrooms. In this scenario, positioning would not involve a revision of curricula or examination content. Here the subject content knowledge of teachers and the introduction of a clear accountability framework would be important.

4.22 A second approach would involve a revision of the content and direction of secondary and higher secondary education. States would introduce content that not only affirms the inculcation of values but also corresponds with the requirement of the labor market and the lifelong learning skills defined within the context of globalization and empowerment discussed above. In this case, improving quality would necessarily involve a more complex and comprehensive approach that includes redesigning curriculum and textbooks, realignment of preservice training as well as inservice training of teachers. Clearly, there is a continuum between the two approaches and reform could begin with the first approach and then evolve into developing the second approach. Table 10 portrays the traditional and lifelong learning approaches. In both scenarios the critical player is the teacher. 
Table 11: Percentage distribution of trained teachers

\begin{tabular}{|lccccccc|}
\hline & \multicolumn{2}{c}{ SE } & & \multicolumn{2}{c}{ HSE } & & \multicolumn{2}{c}{ Inservice training } \\
\cline { 2 - 3 } State & Above HSE & Trained & & Trained & & SE & HSE \\
\hline Andhra Pradesh & 25.98 & 98.35 & & 60.26 & 8.92 & 6.34 \\
\hline Assam & 9.15 & 30.04 & & 28.24 & 10.17 & 11.10 \\
\hline Bihar & 47.25 & 95.71 & & 36.12 & 17.89 & 7.81 \\
\hline Gujarat & 24.75 & 98.39 & & 91.33 & 6.10 & 4.38 \\
\hline Haryana & 32.34 & 98.83 & & 94.51 & & 5.98 & 10.66 \\
\hline Himachal Pradesh & 26.44 & 97.88 & & 75.55 & 8.80 & 12.30 \\
\hline Jammu \& Kashmir & 44.97 & 71.97 & & 73.65 & 30.47 & 25.81 \\
\hline Karanataka & 19.57 & 97.23 & & 64.06 & 11.56 & 10.24 \\
\hline Kerala & 10.14 & 99.08 & & 93.35 & 9.59 & 9.44 \\
\hline Madhya Pradesh & 58.95 & 62.66 & & 74.01 & & 4.46 & 4.69 \\
\hline Maharashtra & 23.00 & 97.18 & & 92.81 & & 16.83 & 9.62 \\
\hline Orissa & 23.40 & 85.02 & & 46.94 & 18.72 & 13.34 \\
\hline Punjab & 39.61 & 98.85 & & 97.39 & 24.20 & 18.61 \\
\hline Rajasthan & 55.37 & 95.70 & 96.35 & 7.60 & 6.96 \\
\hline Tamilnadu & 37.21 & 99.86 & 99.66 & 2.73 & 2.55 \\
\hline Uttar Pradesh & 68.01 & 97.74 & 90.81 & 4.59 & 5.42 \\
\hline West Bengal & 36.32 & 90.89 & 94.53 & 7.12 & 10.10 \\
\hline All India & 32.92 & 91.03 & 83.46 & 11.62 & 9.31 \\
\hline
\end{tabular}

Source: Sixth All-India Education Survey (1993)

How teacher qualifications and professional support relate to the quality of teaching and learning, is a question that needs to be now discussed.

4.23 A teacher's basic qualifications (Table 11) are as important if not more than the professional training received. In case of SE teachers, a higher secondary, and for HSE teachers, an undergraduate degree constitute basic required qualifications. In SE, about one-third of the teachers have higher basic qualifications than is necessary while in the case of HSE, 99 percent of the teachers are either graduates or postgraduates. In fact a large proportion of teachers in Bihar, Madhya Pradesh, Rajasthan and Uttar Pradesh—all States that have large populations-have higher than required qualifications. ${ }^{23}$ In most States, the preservice training qualifications required for secondary school teaching is a Bachelor of Education degree taken after the initial degree in a particular subject area. Similar patterns are evident with regard to preservice training as is evident for prior qualifications. Except for Assam, the proportion of teachers who have been trained is generally high at the secondary level, about 91 percent of teachers instructing SE students in 1993 had received training for teaching. In the case of HSE, the proportion is lower as the eligibility does not necessarily include training as an essential requirement. Post-graduation in specific subjects is given more importance in this case.

4.24 Interestingly, the differences between rural and urban and across different types of schools is not large except in the case of private HSE, which has the lowest percentage of trained teachers. Though students perform better than those in the aided and government schools, there are fewer number of trained teachers in private schools. This suggests that differences in student performance cannot be easily attributed to the differences in just the qualification of teachers. On the one hand,

\footnotetext{
${ }^{23}$ This trend could be because these are economically less developed States and therefore provide fewer employment opportunities. Therefore due to the absence of other options, graduates choose the teaching profession.
} 
it is likely that preservice training, as it is currently structured, has limited impact for both private and public schoolteachers. However, on the other hand, for teachers in the private schools, formative training is likely to be strong while for teachers from rural areas and public schools, the school and undergraduate education are both weak. ${ }^{24}$

4.25 In either scenario discussed earlier, comprehensive changes in preservice training would be needed for integral secondary education reform. The private sector is primarily responsible for the preservice training of teachers in secondary schools. For instance, there are 39 colleges offering B.Ed in Madhya Pradesh, out of which 17 colleges are private institutions. Preservice reform would thus necessarily include both the public and private sectors. In addition, national institutions to develop preservice education were set up over the last few decades. They include the four Regional Colleges of Education, 12 Institutes of Advanced Studies in Education, and University Departments of Education, 22 Colleges of Teacher Education and several private Teacher Training Institutes. The roles, responsibilities and capacities of these institutions would have to be reconsidered when revising preservice

4.26 Entrance criteria as well as the structure and content of preservice training would need rethinking. At present, entrance is based on examination scores, which may not reflect students' abilities to teach. In most States, admission is based on marks obtained in the degree examination, and in some States on marks obtained in entrance examinations. In Himachal Pradesh, for instance, the minimum marks to qualify for admission is 45 percent with a relaxation of 5 percent for SC/ST candidates. With regard to preservice training content, two-thirds of the courses in B.Ed. are theoretical and one-fourth practice-based. The methods and models of education upheld during training are traditional, focusing as Srivastava et al (1999) found, on microteaching, simulations, lesson planning and teaching with aids. If there is to be integral and holistic reform in secondary education, the structure and content of preservice training would have to be revised. Two aspects are important here - the length of practical training and the way in which practice and theory are weighted and connected.

4.27 In order to monitor preservice and to deal with the issue of improving school quality at the national level, the National Council for Teacher Education (NCTE) was established. The NCTE is a statutory body for setting regulatory norms for preservice institutions. These regulations include norms for admission and course content, guidelines for recognition, and standards for evaluation and qualification of instructors. The NCTE regulations until now have focused on the external dimensions of preservice such as infrastructure requirements and qualifications of instructors. Recently, discussions have begun on the content and objectives of training. The NCTE can play an important role in preservice reform, if it is strategically involved in the organization and impact of preservice education in classrooms in States.

4.28 The practice of providing regular inservice training is not common at secondary and senior secondary stages and the majority of teachers undergo a few periods of training after joining the workforce. With reference to existing inservice training, the sessions range from 3 to 30 days. Only 11.6 percent of SE teachers and 9.3 percent of the HSE teachers attended some inservice training in 1993. The proportion of teachers undergoing inservice is the highest in government schools and the lowest in private schools. Training is less frequent in rural areas. According to the 1993 data, in States such as Gujarat, Madhya Pradesh, Rajasthan, Tamil Nadu and Uttar Pradesh, inservice

\footnotetext{
${ }^{24}$ The point made here is that teachers in private schools must have had school and university education in English medium institutions, which are often of a higher quality than vernacular institutions. So the analysis of school achievement based on mere teacher qualifications will not be appropriate or useful. Rather, the issue here is the types of institutions in which teachers have been trained, but this information is not available.
} 
training is particularly weak. The study done on Kerala indicated that systematic inservice training is in place and focuses on difficult areas in the curriculum. Similarly in Himachal Pradesh, inservice training includes "value based" and "content based" programs. No States mention any evaluations done of their inservice training programs. It could be concluded that inservice training is critical, especially for rural and public schoolteachers, to subvert the cumulative influence of teachers' formative and higher education. The institutional location and the organization of appropriate and effective inservice training is important.

\section{B.4 At the Administrative Level}

4.29 The administration of SE and HSE in States is complex and involves several institutions and levels of management. Three main types of institutions appear to be in place to manage this sub-sector: Secretariats, Directorates and Inspectorates. While the Secretariat is the apex policy formulating body, there is considerable variation across States in terms of the number of administrative units responsible for secondary education within the Secretariats and the relative power and responsibility given to them within the sub-sector. In Tamil Nadu for example, while the Secretariat of Education is the apex body, there are four Directorates responsible for secondary education: (i) Directorate of School Education (at the top); (ii) Directorate of Matriculation and Schools; (iii) Directorate of Examinations; and (iv) Directorate of Teacher Education, Research and Training. Departments of Education also exist at the district level, and are headed by District Education Officers.

4.30 In Assam on the other hand, within the Secretariat, the Directorate of Secondary Education is directly responsible for the total functioning of this sub-sector, and is assisted by the Board of Secondary Education and the Assam Higher Secondary Council. The Board and Council are responsible for prescribing courses of instruction and setting the timetable, developing textbooks and instructional material, conducting examinations, setting and ensuring regulatory norms for schools and organizing teacher training. This arrangement is further complicated in States where universities are also involved in providing HSE. Here the Directorates of Higher Education are also involved. It will be critical for SE and HSE, within each State's strategic and comprehensive plan for this level, that there is interaction and collaboration across Directorates, Boards and Inspectorates, and universities for improving the quality of secondary education.

4.31 The process of monitoring of the sub-sector by the State has a profound effect on the quality of education in SE and HSE. The Inspectorates monitor this sub-sector. Inspectorates are usually located both at the State level and in the districts and there are variations across States as to how often and extensive this monitoring is. Furthermore, the policies and expectations and what happens in reality differ considerably. In Orissa, for example, each school has to be monitored once a year. Each Inspector is required to monitor 300 schools and a recent study by NIEPA (2000) reported that only about 30 percent of the schools are visited each year. Reasons for this, according to this study, are not only the large number of schools to be visited and their location but also the large number of court cases that have to be attended to. ${ }^{25}$ The areas that are to be monitored include the extent to which schools follow departmental regulations and curricula, and maintain adequate accounts. Inspectors are supposed to submit a report to the department but they are not required to initiate thinking and a program of action for improving and developing the school. Clearly, the extent to which schools are ensuring levels of instruction and student learning are not being sufficiently monitored.

\footnotetext{
${ }^{25}$ Many studies are now highlighting that the court cases regarding education are severely limiting the amount of time available to administrators for managing education. Reasons for this include the lengthy processes in the judicial system and requirement for educational officials to be present during the discussion and judgment of these cases.
} 
4.32 Staff can be education cadre officers or academicians appointed, nominated or transferred from other departments. Acts, Codes and Regulations form the legal foundation of secondary education. The movement of personnel across departments and the problem of random transfer, for example in States such as Assam and Orissa, limit the effectiveness of the institutions in administering secondary education. In addition, clear performance standards and a system for ensuring that these standards are met, both for the institution and for the individuals in the Secretariats, Directorates and Inspectorates, are not evident.

4.33 The administration of secondary education is centralized at the State level and only a few tasks such as maintenance and disbursement of salaries are devolved to the district level. Regulatory norms for the private sector, especially in States where this sector is sizable, are not sufficiently comprehensive or necessarily performance-based.

4.34 Teacher management is increasingly becoming an area of concern in SE and HSE, which indirectly influences the quality of education. Several dimensions with respect to teacher management can be identified - teacher recruitment, teacher deployment and transfer, and within school, classroom appointments. There are large teacher vacancies in SE and HSE. For example in Karnataka, over half the sanctioned teacher posts for secondary schools have not been filled. If there are so many vacancies in such a relatively better developed State in India, the shortage of teachers in classrooms is likely to be worse in the lesser developed States. Clearly, this will influence the pupil- teacher ratio discussed earlier in this policy note. Teacher deployment is also unsatisfactory and is often influenced by vested interests. Surplus teachers are found in urban areas while posts in rural schools remain vacant. Several transfers of teachers take place after schools start, thus disrupting school functioning. Teacher recruitment, deployment and transfer are areas that require immediate attention across States. Inside schools, there is a problem of teachers appointed to teach in areas that they have not been trained in. Across the country, about 40 percent of the teachers in SE and about 25 percent of the teachers in HSE are not teaching the subjects they have trained in. Within a strategic plan that focuses on school improvement, this issue needs to be necessarily addressed.

4.35 National level institutions dealing with SE and HSE include the NCERT, the NIEPA and the NCTE. There is no documentation, except from the NCTE, on how these institutions are providing support to the States. The outdated data available (not later than the mid 1990's) on SE and HSE indicators portrays the limited capacity in these institutions, which requires attention. It will be useful to develop the ability of these institutions to provide strategic and technical assistance to the States.

\section{Financing Level}

4.36 The financial requirements in secondary education will depend on the intentions of the State and Central governments to improve the quality of secondary education, which appears to be critical and imperative. The amount of financing available would also depend upon whether the services provided by the aided and private sector are optimally utilized to improve SE and HSE, especially for students from the disadvantaged communities. Further, the size of the expansion of this subsector would affect financing requirement. Though enrollment projections have been calculated for six States (Aggarwal 2003), it has not been possible to analyze the financing requirement for these projections. ${ }^{26}$ However, the analysis of financial requirements for secondary education in Karnataka (World Bank 2002b) has been done recently and is reported here.

4.37 Enrollment projections for SE were analyzed based on three scenarios for a set of six States -

\footnotetext{
${ }^{26}$ Clearly, these projections would be altered depending on definitive planning and management of this sub-sector by the different States.
} 


\section{Figure 14a: Enrollment projections}

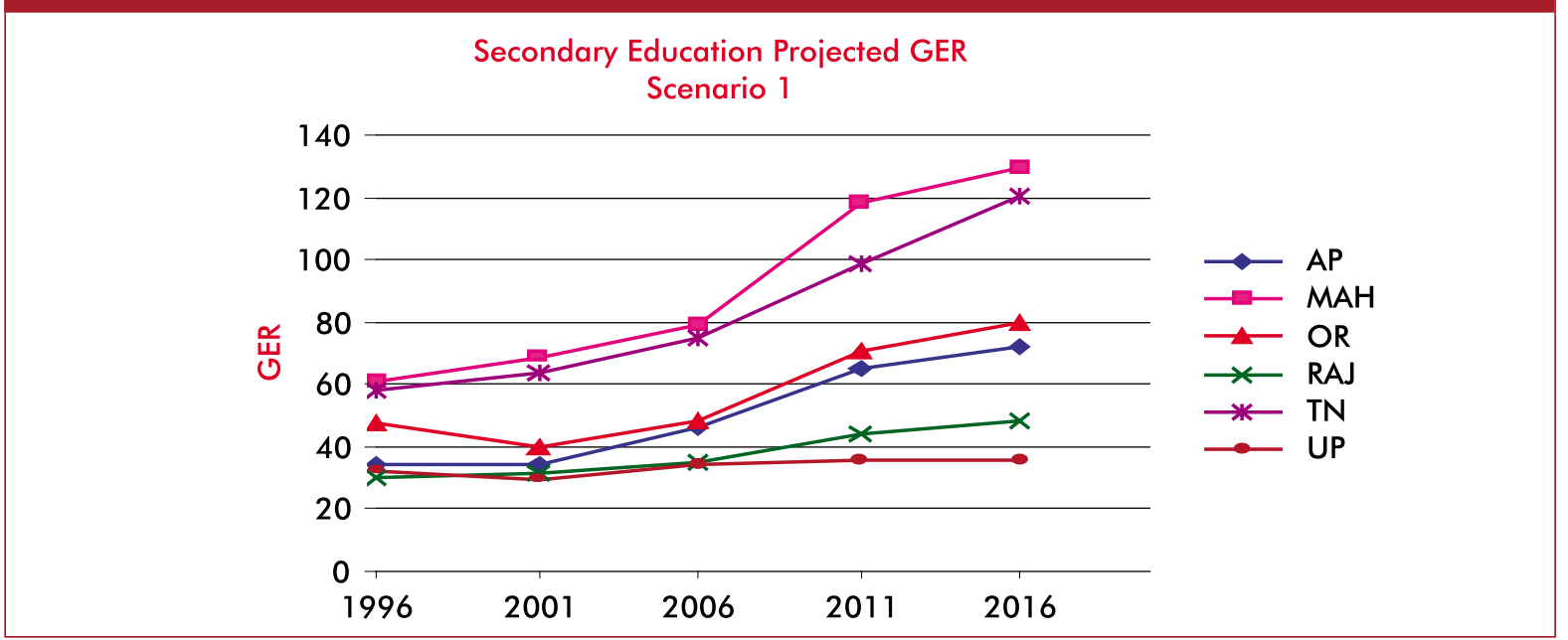

Source Aggarwal 2003

Andhra Pradesh, Maharashtra, Orissa, Rajasthan, Tamil Nadu and Uttar Pradesh, representing different regions in India. Using the linear trend, the first scenario (Figure 14a) is based on enrollments in Grade 8 and 9. Promotion, dropout and repetition remain the same in this analysis. In this scenario, Maharashtra and Tamil Nadu would have universal access to secondary education by 2011. About 60 percent of the students would be enrolled in Orissa and Andhra Pradesh and about 40 percent in Uttar Pradesh and Rajasthan. There is accelerated growth in the first four States after 2006, thus inter-State differentials increase in this scenario. In the second scenario (Figure 14b), student flow model is used and projections have been derived based on the population that entered school, intake rates and flow rates of students from one grade to the next. The impact of the District Primary Education Project (DPEP) and the Sarva Shiksha Abhiyan (SSA) are also considered in this model. The projections demonstrate a much slower growth rate and reduced differentials across States. By 2011, Maharashtra and Tamil Nadu reach only 60 percent, Orissa 50 percent; Andhra Pradesh 40 percent and Rajasthan and Uttar Pradesh 20 percent. The third

\section{Figure 14b: Enrollment projections}

Secondary Education Projected GER

Scenario 2

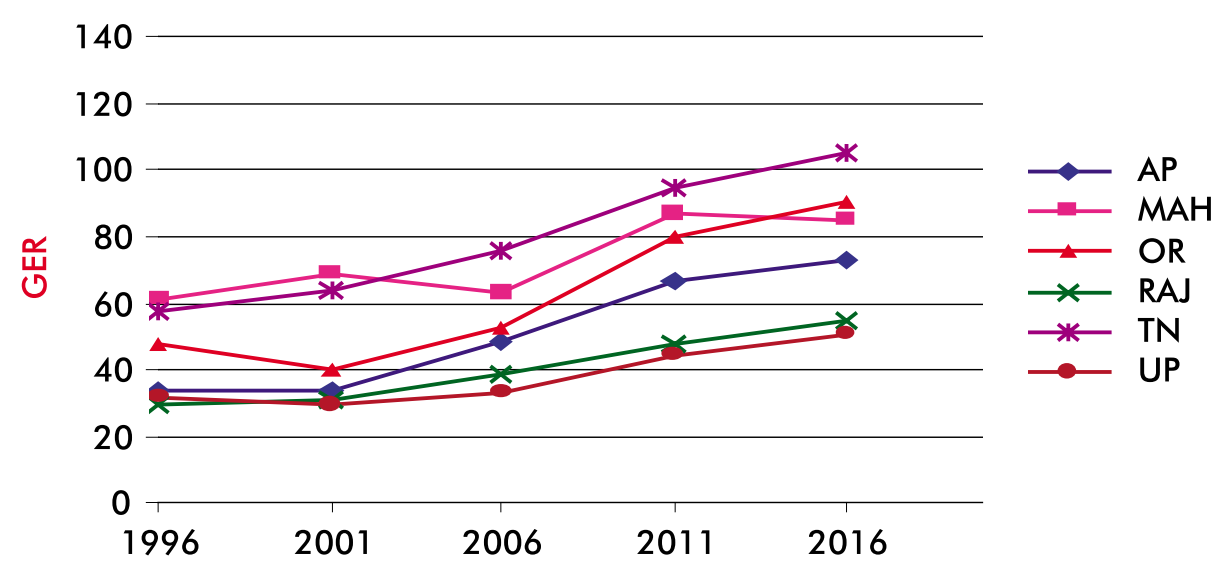

Source Aggarwal 2003 
Figure 14c: Enrollment projections

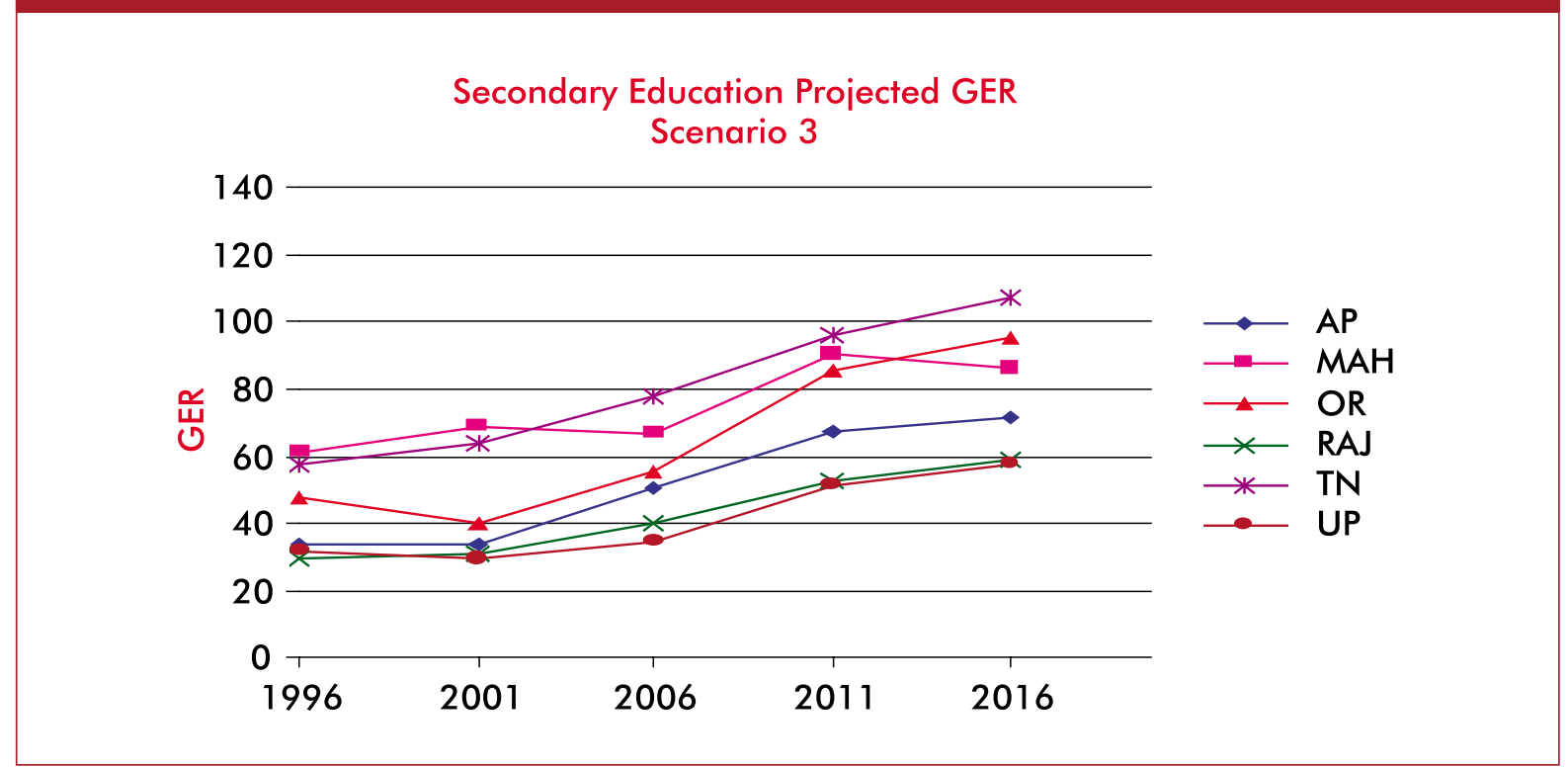

Source Aggarwal 2003

scenario (14c) is similar to the second except that there is more improvement in the internal efficiency in the system. The trend is similar but higher levels are reached by 2011. While gender disparities show improvement in all three scenarios, the situation in Rajasthan and Uttar Pradesh is not so encouraging with girls' share of total enrollment only reaching about 30 percent by 2011 .

4.38 Independent of the three scenarios cited above, financial projections have been made for SE in Karnataka using three different scenarios (Table 12). Transition rates are low between Grades 8 and 9 in the first scenario; revised pay scales for teachers are considered in the second scenario; and transition rates are high without revised pay scales for teachers in the third scenario. The costs included here only relate to physical infrastructure (classrooms, salaries and toilet facilities) and quality improvements include libraries, laboratories, computer education, teacher training, academic support to teachers, replacement costs for books, equipment and maintenance. The projections indicate a considerable increase in expenditure on secondary education over the next four years. Clearly, the importance of SE and HSE cannot be underestimated, which also indicates that the investments made in secondary education will also have to be sizable and strategic. According to Godo (2002), developing countries must be prepared to bear the burden of such investments relative to their income before the stock of human capital can reach a level adequate to influence economic development.

\section{CONCLUSIONS}

5.1 Secondary education is becoming increasingly important in developing countries, which have so far concentrated on achieving universal elementary education. The discussion above has highlighted issues and constraints in secondary education that require concerted attention both in terms of policies and directions for implementing reform. Overall, it would be useful to locate reform in secondary education within one of the two scenarios available to national and State governments conveyed throughout this note. The first scenario would involve improving quality within the current system, thus improving efficiency and student performance. The second scenario is to reform the whole direction of this level of education to develop students who know how to learn and acquire skills for lifelong learning, allowing them to respond effectively to global labor markets. This section 


Table 12: Costs for financing secondary education in Karnataka (Rs. Crore)
\[ \begin{array}{r}2003-04 \\ \text { Grades 9-10 Grades 9-10 Grades 9-10 Grades 9-10 }\end{array} \]

\begin{tabular}{|c|c|c|c|c|}
\hline \multicolumn{5}{|l|}{ To be borne by Government } \\
\hline \multicolumn{5}{|c|}{ Expanding and Maintaining Facilities } \\
\hline Low Transition Rate (no pay increase) & 554 & 599 & 638 & 793 \\
\hline Low Transition Rate (with pay increase) & 885 & 615 & 664 & 708 \\
\hline $\begin{array}{l}\text { High Transition Rate } \\
\text { (no pay commission increase) }\end{array}$ & 640 & 691 & 845 & 1054 \\
\hline \multicolumn{5}{|l|}{ Improving quality } \\
\hline Low Transition Rate (no pay increase) & 74 & 84 & 94 & 112 \\
\hline Low Transition Rate (with pay increase) & 78 & 88 & 99 & 118 \\
\hline $\begin{array}{l}\text { High Transition Rate } \\
\text { (no pay commission increase) }\end{array}$ & 80 & 90 & 107 & 128 \\
\hline \multicolumn{5}{|l|}{ Total } \\
\hline Low Transition Rate (no pay increase) & 629 & 683 & 732 & 905 \\
\hline Low Transition Rate (with pay increase) & 693 & 752 & 807 & 999 \\
\hline $\begin{array}{l}\text { High Transition Rate } \\
\text { (no pay commission increase) }\end{array}$ & 719 & 781 & 952 & 1182 \\
\hline \multicolumn{5}{|c|}{ B. Capital expenditure in aided schools } \\
\hline Expanding and maintaining facilities & 24 & 25 & 19 & 19 \\
\hline Improving quality Maintenance grant & 27 & 36 & 46 & 57 \\
\hline Total & 510 & 610 & 660 & 760 \\
\hline
\end{tabular}

Source: $W B 2002 b$

will summarize critical areas and issues that this note has highlighted in secondary and higher secondary education (in schools). These areas are: planning in secondary and higher secondary education, administration, educational quality and financing of secondary education.

\section{Planning in Secondary Education}

5.2 Planning for secondary education involves both national and State governments. Thus far the involvement of the Center with the State has been piece meal and focuses on implementing national programs within States. This policy note suggests a far more strategic involvement of the Central government with the States. ${ }^{27}$ This kind of strategic involvement is envisioned within the Government of India's $10^{\text {th }}$ Plan; however, it would need to be operationalized. Possible direction for such strategic involvement could be to encourage and enable States to comprehensively plan for secondary education reform, focusing on areas identified in the $10^{\text {th }}$ Plan such as equity, quality, and so on. Thus rather than the Center deciding on a plan for developing particular areas of secondary education in the States, States could develop their own plans which could then be supported by the Center. Support to the States could be based on a clear set of performance indicators. In this situation, the Center would also develop a range of technical resources, which States could draw upon depending on the focus and needs defined in their plans.

5.3 Strategic planning at the State level is not clearly evident in most States. State level planning has so

${ }^{27}$ The case of Argentina is pertinent here. Gorostiaga et al (2002) discuss the case of Argentina where decentralization took place in 1993. Within the scenario of decentralization the Center emerges as a strong and strategic force in education. 
far involved the allocation of Central funding and a continuation of the previous year's activities. In order to begin the process of planning, a situational analysis of education in each State would be necessary. If a plan for reform is developed based on such an analysis, it would allow for a more coherent and comprehensive approach to SE and HSE. A situational analysis would highlight specific issues in each State, which could then be included in the strategic plan for the State. For example, infrastructure needs in some States appear to be much greater than in the others. On the other hand, in the Southern States, the need to improve educational quality seems much more significant. District level planning is also not evident. Decentralization as it is now in practice does not insist that local governments plan for the education in their districts and be accountable for ensuring its quality. Strategic responsibilities within a framework of incentives given to local governments could help improve the provision of SE and HSE in rural areas.

\section{Management and Administrative Reforms}

5.4 Four aspects can be identified here. Firstly, the many institutions involved in SE and HSE at the State level currently appear to be operating independent of each other. This is perhaps due to the absence of an overall vision for the sub-sector. Depending on how States' decide to position their SE and HSE sectors, it will be critical to focus on a more effective functioning of these institutions aligned within this vision. Institutional capacity building and reform would be located within the development of this vision. Secondly, in order to improve secondary education, reform in teacher management requires attention. An adequate number of teachers, transparent and effective transfer and deployment policies and systematic and focused professional development will reduce the constraints on improving secondary education. Thirdly, if the grant-in-aid is to be revived or the voucher program is put in place so as to reduce the burden on government schools, at the same time support equity and private-public partnerships, revised funding mechanisms, regulatory and monitoring norms at the institutional level would have to be established.

5.5 Fourthly, in order to manage the sector more efficiently it would be critical to put in place a computerized monitoring information system for such important indicators such as enrollment and retention. With reference to enrollment data, States are at different levels of sophistication. Some States are able to provide fairly detailed analysis of the data while others are less capable of doing so. At the national level, data on infrastructure and teachers in secondary education is only available for mid-1990. It will also be important to ensure that up-to-date information is collected on enrollments, retention and completion. Another important tool to monitor system efficiency is the implementation of an assessment system. So far the focus has been on examinations, which really tests the individual student. Similar to the DPEP, an assessment system based on random sampling would capture the extent to which the system is functioning across States and districts. The connections between performance and the different educational indicators or inputs into education would be useful for planning and management in this sub-sector. In the event that a national assessment system is established, it will be possible to examine relationships between enrollment trends and performance, especially with regard to disadvantaged communities.

\section{Quality Improvement}

5.6 The performance of students in both SE and HSE portrays a critical need to improve the quality of instruction in SE and HSE schools. All the aspects related to quality require considerable attention - infrastructure, school improvement and teachers' professional development. Again based on the positioning of this level of education, the specific areas within the area of infrastructure would be considered first. If the intention here is to continue the current curriculum and examination model, infrastructure needs would focus on laboratories rather than libraries. Teacher training in subject 
content knowledge and accountability systems for teachers and for schools would also be necessary. If on the other hand, life long learning skills become important then both libraries and laboratories will be important. School improvement and teachers' professional development through reform in preservice would be of paramount importance. Institutional reform (textbooks, curriculum and examinations) as well as intensive inservice training would be needed. A specific reference needs to be made here to IT education. In the current scenario where IT education is mainly confined to making students computer literate, it will be sufficient to introduce computers to students for a relatively short period of time. However, if computers are used to enhance and deepen core subject content knowledge, students would require them for longer lengths of time. The point here is that there is a wide variety in the infrastructure requirements for IT in schools, which depends on the overall objectives of the curriculum.

5.7 Vocational education is an area that requires rethinking. The success of most of the States that have attempted to implement the Centrally sponsored scheme of vocational education has been limited, especially when the size of the investments made for vocational education is considered. The importance of generic skills has been highlighted. In addition, the "vocational" part of the program could be redesigned with the direct involvement of industry and employers. If industry and employers are not willing to participate in providing vocational training, it seems that providing all students with generic life skills could be a more appropriate option.

\section{Financing}

5.8 Thus far the focus, rightly so, has been on elementary education. Increasingly the significance of secondary education to the country's economic progress is becoming critical. If there are going to be concerted efforts at secondary education reform, the current level of funding for secondary education is insufficient, and especially lacking for critical quality improvements in this sub-sector. While State level increases in financial allocation is critical, the need for clear incentives and performance indicators associated with Central allocations to States would be important.

5.9 This policy note on secondary education has attempted to highlight significant issues in secondary education in India. The analysis is based on the performance of this sub-sector on basic indicators including enrollment retention and completion. Clearly, considering its impact on economic development, which is increasingly becoming evident, this sub-sector requires attention. It is likely that this sub-sector will expand as the enrollment in elementary education increases. It will be important to ensure targeted expansion that supports equity, particularly with regard to girls, and students from Schedule Caste and Schedule Tribe communities. Redirecting the vision of secondary education to prepare students for the fast paced and changing work environment and improving the quality of education provided are also seen as critical to the development of this sub-sector. This requires corresponding policy, administrative and financial decisions to be made that are appropriate and supportive of the reform. 


\section{Annexure \\ Critical research and policy analysis for addressing needs in secondary education}

- Situational analysis of secondary education at the State level.

- Projecting financial needs in this sub-sector and increasing financing of secondary education. Financing could also be targeted for girls and students from SC and ST communities.

- Understanding the financial requirements and policies for effective vocational educational and the use of IT in education. It will be useful to examine the cost effectiveness of the current vocational education stream and to consider forming partnerships with the private sector and industry to formulate appropriate and cost effective vocational education programs. In many States the private sector has been involved with introducing IT in education on a pilot basis. It will be useful to analyze the experience of these initiatives for further involvement and scaling up.

- Setting up of data information systems at the state level that monitors educational outcomes. In order to maintain an information base that captures the entire secondary education scenario, it will be important to include information for both the public and private schools.

- Organizing State Councils for Educational Research and Training (SCERT) and the State Institutes for Educational Management, Administration and Training (SIEMAT) for policy analysis and support of secondary education. These institutions have thus far dealt primarily with the needs of the elementary education sub-sector. Planning and reorganization is required to include the area of secondary education within these institutions.

- Re-examining the policy on grant-in-aid and exploring the possibility of introducing the voucher scheme especially for encouraging girls' enrollment and participation. The private sector is significantly involved in education in many States. Since the students from low-income groups rarely make use of private sector education, the contribution of aided schools is critical in this regard. Vouchers, effective in some countries especially in urban areas, could be introduced on a pilot basis for girls.

- Assessment and capacity building of Examination Boards and Textbook Boards. The revitalization of these Boards would need to be in line with the objectives of secondary education conceptualized at the State level.

- Revising curricula and examinations to focus on the development of skills for lifelong learning. Curriculum and textbook revision and transforming pedagogy are important aspects of the former. With regard to the latter, the targeting of examinations towards testing the application and problem solving skills of students would be critical. This would need to be supported by the establishment of a system of National Assessments to monitor effectiveness and quality of secondary education for planning purposes.

- Planning for the professional development of teachers by revising preservice training and introducing systematic inservice training. Revising preservice would involve working with the private sector which is the main providers of preservice training. In addition to planning the content, the sufficiency of manpower and institutional location for inservice would need to be considered.

- Addressing the infrastructure needs in the sector. 


\section{Reference}

Acedo, Clementina (ed). (2002). Case studies in secondary education Reform. Washington DC: U.S. Agency for International Development.

Aggarwal, Yash. (2001). Perspectives on secondary education in India. New Delhi: National Institute for Educational Planning and administration.

Bagnall, Nigel. (2000). The balance between vocational secondary and general secondary schooling in France and Australia. Comparative Education 36(4) pp. 459-475.

Bashir, Sajitha. (2000). Government expenditure on elementary education in the nineties. New Delhi: The European Commission.

Bennell, Paul and Segerstrom, Jan,. (1998). Vocational education and training in developing countries: Has the World Bank got it right? International Journal of Educational Development, vol. 18, No. 4, pp. 271-287.

Bolina, P. (1995). Vocational education in India. New Delhi: Sterling Publishers Private Limited.

Castro, Claudio de Moura; Carnoy, Martin and Wolff, Laurence. (2000). Secondary schools and the transition to work in Latin America and the Caribbean. Washington DC: Inter-American Development Bank.

Clarke, Prema. (2001). Teaching and Learning: The culture of pedagogy. New Delhi: Sage Publications.

Clarke, Prema and Fuller, Bruce. (1997). Life in the Indian classroom: The influence of culture and caste. Indian Educational Review, 32 (2), pp. 47-68.

Duraisamy, P. and Subramanian, T.P. (1999). The relative effectiveness of public and private higher secondary schools in an urban center in India. Journal of Educational Planning and Administration, 13 (1), pp. 37-52.

Encyclopedia of Education, $2^{\text {nd }}$ Edition. (2003). New York: Macmillan Reference.

Fretwell, David and Wheeler, Antony. (2001). Hungary: Secondary education and training. Washington DC: World Bank.

Fretwell, David and Wheeler, Antony. (2001). Poland: Secondary education and training. Washington DC: The World Bank.

Gauri, Varun and Vawda, Ayesha. (2003). Vouchers for basic education in developing countries. Washington DC: World Bank Policy Research Working Paper 3005.

Godo, Yoshihasa. (2002). Accumulation of education in modern economic growth: A comparative study between Korea, Japan and USA. Paper presented at the HDNED May 7, 2002.

Government of India. (2001). Literacy and levels of education in India, 1999-2000. New Delhi: $\mathrm{NSSO}, 55^{\text {th }}$ round. GOI.

Government of India. (2001). Report of the working group on vocational education for the Tenth Plan 2002-2007. New Delhi: Ministry of Human Resource Development.

Government of India. (2001). Report of the working group on secondary education for the Tenth Plan 2002-2007. New Delhi: Ministry of Human Resource Development. 
Government of India. (1998). Attending an Educational Institution in India: Its level, nature and cost, 1995-96. New Delhi: National Sample Survey Organization (NSSO).

Government of India. (1997). Remodeling of school Boards. New Delhi: Ministry of Human Resource Development.

Inter-American Development Bank. (2000). Reforming primary and secondary education in Latin America and the Caribbean. Washington DC: Inter-American Development Bank.

Linden, Toby. (2001). Double shift secondary schools: possibilities and issues. Washington DC: The World Bank.

Majumdar, Manabi. 2001. "The educational challenge before the 'Knowledge Economy': Implications for planning and financing", Perspectives in Education, vol. 17, pp.19-35.

Manpower Profile. (2001). India Yearbook. New Delhi: Institute of Applied Manpower Research.

Marlow-Ferguson, Rebecca (ed). (2002). A survey of education systems worldwide. World Education Encyclopedia, Volume I \& II. Framington Hill, MI: Gale Group.

Mehta, Arun. (2000). Universalisation of secondary education: present status and future prospects with focus on enrolment projections in India. New Delhi: National Institute for Educational Planning and Administration.

Mukhopadhyay, Sudesh and Anil Kumar K. (2001). Quality profiles of secondary schools. New Delhi: National Institute for Educational Planning and Administration.

National Council for Education Research and Training. (1999). National curriculum framework for school education. (1999). New Delhi.

National Council for Education Research and Training. (1998). Sixth All India Educational Survey, Vols. II-VII. New Delhi.

National Institute for Education Planning and Administration. (2001)."Focus Secondary Education”. Report of the National Conference, February, 2001. New Delhi.

Saxena, Ajay Kumar; Saxena, Praveen and Saxena, Prem K. (2000). On the use of computers in secondary education. The Rajasthan Board Journal of Education, 39 (4), pp. 46-49.

Shariff, Abusaleh and Ghosh, P. K. (2000). Indian education scene and the public expenditure gap. Economic and Political Weekly, vol. 35, April 15, 2000.

Srivastava, G.N. Prakash and Aggarwal, I. P. (1999). Restructuring secondary teacher training: a prospective model. Journal of Indian Education. 25 (1), 22-36.

Tharakan, P.K. Michael and Navaneethan, K. (2000). Population projection and policy implications for education: a discussion with reference to Kerala. Review of Development and Change, vol.5, pp. 2451.

Tyagi, R.S and Mahapatra, P.C. (2000). Educational administration in Orissa. National Institute of Educational Planning and Administration. New Delhi: Vikas Publishing House.

Tyagi, R.S. and Paramasivan, S. (2001). Educational administration in Tamil Nadu: structures, processes and future prospects. National Institute for Educational Planning and Administration. New Delhi: Vikas Publishing. 
UNESCO. (2000). World Education Report. Paris: UNESCO Publishing.

World Bank. (2003). Lifelong learning in the global knowledge economy. Washington DC: The World Bank.

World Bank. (2002a). India: Karnataka: Financing education in the context of economic restructuring. Washington DC: Report No. 24207-IN. The World Bank.

World Bank. (2002b). India: Secondary education and the new agenda for economic growth. Washington DC: Report No. 24208-IN. The World Bank.

World Bank. (2001). Brazil: Teachers' development and incentive - a strategic framework. Washington DC: Report No. 20408 BR. The World Bank.

World Bank. (2000). Secondary education in Brazil: time to move forward. Report No. 19409 IBRD; BR-014IDB. Washington DC: The World Bank.

Xiaogyan, Liang. (2001). China: Challenges of secondary education. Washington DC: The World Bank.

Yang, Jin. (1998). General or Vocational? The tough choice in the Chinese education policy. International Journal of Educational Development, vol. 18, No. 4, pp. 289-304. 